\title{
Gene expression in whole lung and pulmonary macrophages reflects the dynamic pathology associated with airway surface dehydration
}

Yogesh Saini, ${ }^{*}$ Hong Dang, Alessandra Livraghi-Butrico, Elizabeth J Kelly, Lisa C Jones, Wanda K O’Neal ${ }^{\dagger}$ and Richard C Boucher ${ }^{\dagger}$

\begin{abstract}
Background: Defects in airway mucosal defense, including decreased mucus clearance, contribute to the pathogenesis of human chronic obstructive pulmonary diseases. Scnn1b-Tg mice, which exhibit chronic airway surface dehydration from birth, can be used as a model to study the pathogenesis of muco-obstructive lung disease across developmental stages. To identify molecular signatures associated with obstructive lung disease in this model, gene expression analyses were performed on whole lung and purified lung macrophages collected from Scnn 16 -Tg and wild-type (WT) littermates at four pathologically relevant time points. Macrophage gene expression at 6 weeks was evaluated in mice from a germ-free environment to understand the contribution of microbes to disease development.

Results: Development- and disease-specific shifts in gene expression related to Scnn $1 b$ over-expression were revealed in longitudinal analyses. While the total number of transgene-related differentially expressed genes producing robust signals was relatively small in whole lung $(n=84)$, Gene Set Enrichment Analysis (GSEA) revealed significantly perturbed biological pathways and interactions between normal lung development and disease initiation/progression. Purified lung macrophages from Scnn $1 b$-Tg mice exhibited numerous robust and dynamic gene expression changes. The expression levels of Classically-activated (M1) macrophage signatures were significantly altered at post-natal day (PND) 3 when Scnn1b-Tg mice lung exhibit spontaneous bacterial infections, while alternatively-activated (M2) macrophage signatures were more prominent by PND 42, producing a mixed M1-M2 activation profile. While differentially-regulated, inflammation-related genes were consistently identified in both tissues in Scnn1b-Tg mice, there was little overlap between tissues or across time, highlighting time- and tissue-specific responses. Macrophages purified from adult germ-free Scnn1b-Tg mice exhibited signatures remarkably similar to non-germ-free counterparts, indicating that the late-phase macrophage activation profile was not microbe-dependent.
\end{abstract}

Conclusions: Whole lung and pulmonary macrophages respond independently and dynamically to local stresses associated with airway mucus stasis. Disease-specific responses interact with normal developmental processes, influencing the final state of disease in this model. The robust signatures observed in Scnn 1b-Tg lung macrophages highlight their critical role in disease pathogenesis. These studies emphasize the importance of region-, cell-type-, and time-dependent analyses to fully dissect the natural history of disease and the consequences of disease on normal lung development.

Keywords: Scnn1b-Tg mice, Pulmonary macrophage activation, Inflammation, Mucus clearance defect, Gene expression profiling, Lung development, Airway surface liquid dehydration

\footnotetext{
*Correspondence: yogesh_saini@med.unc.edu

'Equal contributors

Marsico Lung Institute/University of North Carolina Cystic Fibrosis Center,

School of Medicine, University of North Carolina at Chapel Hill, 7011

Thurston Bowles Building, Chapel Hill, NC 27599-7248, USA
}

\section{Biomed Central}

(c) 2014 Saini et al.; licensee BioMed Central Ltd. This is an Open Access article distributed under the terms of the Creative Commons Attribution License (http://creativecommons.org/licenses/by/4.0), which permits unrestricted use, distribution, and reproduction in any medium, provided the original work is properly credited. The Creative Commons Public Domain Dedication waiver (http://creativecommons.org/publicdomain/zero/1.0/) applies to the data made available in this article, unless otherwise stated. 


\section{Background}

Defects in mucus clearance are characteristic of mucoobstructive pulmonary diseases of genetic or environmental origins, e.g., cystic fibrosis (CF), primary ciliary dyskinesia (PCD), and the chronic bronchitic (CB) form of chronic obstructive pulmonary disease (COPD) [1]. Airway mucus clearance is a multifactorial process, integrating epithelial mucin secretion and airway surface hydration with ciliary beat, cough, and/or gas-liquid pumping [2,3]. While airway remodeling and inflammation often accompany defective mucus clearance $[1,4]$, the mechanisms linking defective mucus clearance to obstructive lung disease are poorly understood. One paradigm is that defects in mucus clearance produce static mucus that provide a nidus for microbial colonization and resultant inflammatory responses [5]. While this concept is supported by the presence of pathogens in lungs of patients exhibiting defects in mucus clearance [6-8], the roles of the primary defects (airway surface liquid dehydration, dehydrated/concentrated mucus, lack of ciliary beat, decreased mucus clearance) in establishment of chronic inflammation are not fully appreciated. Additional complexity arises when the consequences of mucus obstruction are considered in the context of normal lung development and aging, i.e., mucus obstruction early in life (CF, PCD) may generate long-term effects that would not occur if the obstruction occurs later (CB, COPD).

To model defective airway mucus clearance in vivo, transgenic mice over-expressing the epithelial sodium channel beta subunit $[\beta E N a C$, encoded by the Scnn $1 b$ (Sodium channel non-voltage-gated 1, beta subunit) gene] in airway club cells (previously referred to as Clara cells, or known as CC10-expressing secretory cells) were generated [9]. The initiating pathophysiological defect in these mice, i.e., airway surface liquid (ASL) depletion, produces mucus dehydration, reduced mucus clearance, and overt pulmonary disease characterized by airway mucus obstruction, inflammation, and spontaneous bacterial infection [9-13]. At birth, the lungs of Scnn1b transgenic (Scnn1b-Tg) mice are histologically normal. During the early neonatal period, i.e., post-natal day (PND) 3-10, significant tracheal mucus plugs develop that are associated with neonatal mortality and distal airway hypoxia [10-12]. Transient necrotic degeneration of intrapulmonary club cells is also observed around PND 3 [12]. Macrophage activation, neutrophilia, and bacterial infection are detected as early as PND 5 [13]. Importantly, because murine lungs continue to mature during early post-natal life [14], the disease processes from PND 3-10 are occurring during periods of active lung development, which has relevance for lung diseases such as bronchopulmonary dysplasia (BPD) and early childhood exposures to toxic or infectious agents, i.e., smoke or viral infections, where inflammatory processes and development intersect to produce long-term, negative consequences for lung function [15-18]. After PND 10, mucus obstruction becomes more prominent in the main stem bronchi of the Scnn1b-Tg mice, airway inflammation becomes more modest, bacterial infection is intermittent, yet bronchoalveolar lavage (BAL) mucin content and mucin gene transcription remain elevated [12,19]. Further, alveolar air space enlargement becomes clearly evident, and the incidence of bronchus associated lymphoid tissue (BALT) increases $[10,13]$.

Pulmonary macrophages carry out important gatekeeping roles in host defense [20]. As resident innate immune cells, they must remain quiescent in the healthy state, yet they must be able to respond when lung homeostasis is threatened. In health and disease, crosstalk occurs between the airway epithelium and macrophages via either receptor-mediated cellular interactions [21] or through humoral signals released by either cell types [22]. The airway epithelium is the epicenter of disease initiation in the Scnn $1 b$-Tg mice, and macrophages are strategically positioned to respond to defects in airway clearance. A consistent feature of disease in the Scnn1b-Tg mice is the presence of morphologically activated pulmonary macrophages [13]. Macrophages are morphologically activated early (by 3 days of age), and previous work identified upregulation of genes associated with macrophage activation, including chitinases, IL-13, and other cytokines [12]. Macrophage-derived protease, Mmp12, is critical for the development of the emphysema in Scnn1b-Tg mice [23]. Germ-free Scnn1b-Tg mice exhibit lung pathology, including morphological activation of macrophages, very similar to $S c n n 1 b$-Tg mice raised in specific pathogen free (SPF) conditions, indicating that the macrophages respond directly to the primary defect of airway surface dehydration and mucus stasis [13].

Genetic and pharmacologic studies suggest activation of multiple signaling pathways in response to defective mucus clearance in the Scnn1b-Tg mice. For example, genetic disruption of major pathways conventionally associated with airway inflammation and remodeling, e.g., MyD88 and IL-4R $\alpha$, did not dramatically alter disease development [13,24], highlighting the need to explore additional disease-promoting pathways. In the present study, we hypothesized that disease-associated molecular signatures linked to key host response, e.g., airway inflammation and mucus cell metaplasia, could be identified by evaluating gene expression in selected tissues from Scnn1b-Tg mice at critical time points. Accordingly, we selected the following time points: 1 ) immediately after birth (PND 0, i.e., <24 hours), when the transgene is overexpressed but disease is not yet manifested histologically; 2) at PND 3, when tracheal mucus obstruction is prominent; 3) at PND 10, when chronic lower respiratory disease is being initiated; and 4) at PND 42, after 
establishment of chronic pulmonary disease. Gene-level and pathways analyses were used to generate a picture of differential gene expression in whole lung and macrophages. The results highlight a highly dynamic interplay of tissue-specific and time-dependent responses and set the stage for future studies to explore these complex interactions.

\section{Methods}

\section{Mice and animal husbandry}

Congenic C57BL/6N Scnn1b-Tg mice and WT littermates were maintained in a specific pathogen free (SPF) animal facility [10]. Germ-free (GF) mice were maintained in the National Gnotobiotic Rodent Resource Center at UNC [13]. Animals used in this study were maintained and studied under protocols approved by the University of North Carolina Institutional Animal Care and Use Committee.

\section{Lung RNA isolation}

Tissues were collected from male mice at a designated time $(1: 00 \mathrm{pm})$. The lung left lobe was removed by cutting the extrapulmonary bronchus at the level of the hilum. Dissected tissue was stored in RNAzol (QIAzol lysis reagent, Qiagen Sciences, Valencia, CA) at $-20^{\circ} \mathrm{C}$. RNA was prepared using Qiagen RNeasy Mini Kit (Qiagen Sciences, Valencia, CA; following protocol recommended for animal tissue) followed by ammonium acetate precipitation. To minimize the effect of biological variation between individual animals, total RNA from three age- and genotype-matched mice were pooled to constitute each sample. A total of three RNA samples were analyzed at each time point for WT and Scnn $1 b$-Tg mice.

\section{Macrophage RNA preparation}

Male Scnn1b-Tg mice and WT littermates were anesthetized with an intraperitoneal administration of 2,2,2 tribromoethanol (T48402, Sigma, St. Louis, MO). The lungs were lavaged at least 4 times with calcium- and magnesium-free DPBS supplemented with $0.5 \mathrm{mM}$ EDTA with the volume determined on weight-based formula [13]. Magnetic-activated cell sorting (MACS) was used to purify macrophages using Anti-Ly-6G MicroBead Kit (130-092-332, Miltenyi Biotech, MA). This approach selectively deplete granulocytes that predominantly express Ly-6G as a surface marker [25]. Since BAL cells include granulocytes, macrophages, lymphocytes and occasional dendritic and epithelial cells, the Ly-6G negative fraction, in addition to macrophages, is expected to include lymphocytes, dendritic cells and epithelial cells, but these cells are rare in these preparations. BALs cell pellets were suspended in $200 \mu \mathrm{l}$ of MACS buffer. $50 \mu \mathrm{l}$ of anti-Ly-6GBiotin solution was added followed by incubation at $4{ }^{\circ} \mathrm{C}$ for $10 \mathrm{~min}$. Subsequently, $100 \mu \mathrm{l}$ of anti-biotin microbeads and $150 \mu \mathrm{l}$ of MACS buffer were added followed by incubation at $4^{\circ} \mathrm{C}$ for 15 minutes. Cell pellets washed with $10 \mathrm{ml}$ MACS buffer were dissolved in $500 \mu \mathrm{l}$ of MACS buffer. Thereafter, macrophage isolation through negative selection was carried out according to manufacturer's recommendations. Ly-6G negative cells (predominantly macrophages) were pelleted, snap-frozen, and stored at $-80^{\circ} \mathrm{C}$. At PND 0, PND 3 and PND 10 time points, total macrophages collected from three genotype-matched pups were pooled to generate each sample. Each sample at PND 42 time point represents macrophages collected from individual mice. Frozen macrophage pellets were lysed and homogenized in lysis buffer and QIAshredder (Qiagen, Valencia, CA). Genomic DNA was eliminated using gDNA eliminator spin columns (Qiagen, Valencia, CA). The RNA was isolated using Purelink RNA mini kit (Invitrogen, NY).

\section{cDNA generation and microarray}

12 ng RNA was used to generate cDNA using Ovation Pico WTA system V2 kit (NuGEN Technologies, CA). Total RNA or cDNA samples were submitted to the UNC Functional Genomics Core for cDNA preparation and hybridized to Affymetrix Mouse Gene 1.0 ST arrays according to the manufacturer's instructions (Affymetrix Inc., Santa Clara, CA).

\section{Microarray data analysis}

Probe level intensities from Affymetrix GeneChip Scanner 3000 in .CEL files were evaluated for quality by whole array statistics using Affymetrix Expression Console software. Gene expression analyses were performed using Partek Genomics Suite v6.6 (Partek Inc., St. Louis, MO). Briefly, probeset intensities were extracted from .CEL files by RMA background correction following GC content and sequence adjustments, normalized using quantile normalization, and gene level intensities were summarized through median polish, based on a modified meta-probeset mapping (.mps) derived from Affymetrix latest transcript annotation (release na33.2 $\mathrm{mm} 9$ ). The meta-probeset mapping consolidated all probesets to unique gene identifiers parsed from Affymetrix transcript annotation with the following precedence: ENSEMBL gene, Refseq mRNA, and Genbank nucleotide identifiers. Data quality, batch effect, and sample groupings were assessed by Principle Component Analysis (PCA) with correlation dispersion matrices. Differential gene expression was analyzed using ANOVA and linear contrast between experimental groups. The resultant differential expression (DE) p-values were adjusted for Multiple Test Correction using the False Discovery Rate (FDR) by Benjamini-Hochberg method [26].

Differentially expressed genes (DEG) were obtained through the combination of selected p-value and fold 
change filters (as indicated in figure legends), and normalized $\log 2$ intensities from individual arrays of DEGs were extracted for hierarchical clustering. Normalized $\log 2$ intensities were used in Gene Set Enrichment Analyses (GSEA) against gene sets derived from Biological Processes of the current Gene Ontology (GO) annotation database and custom gene sets relevant to lung disease and cellular physiology. Visual representations of GSEA enrichment FDR q-values from multiple sample groups were generated by hierarchical clustering of the transformed q-values using Cluster3 [27] and Java TreeView [28]. Detailed data mining of GSEA results from related GO vocabulary terms was performed by extracting relationships between functional terms from the current GO flat file download, and visualizing the resultant networks decorated by specific enrichment FDR qvalues with Cytoscape [29]. The complete expression dataset has been submitted to the Gene Expression Omnibus (GEO) database with the accession number of GSE47551. http://www.ncbi.nlm.nih.gov/geo/query/acc. cgi?acc=GSE47551.

\section{Protein extraction and western blotting}

Total protein was extracted from BAL macrophages after lysing with Radioimmuno Precipitation Assay buffer supplemented with $0.5 \mathrm{mM}$ EDTA, $0.1 \mathrm{mM}$ DDT and Halt protease inhibitors (Thermoscientific, Rockford, IL). Proteins were separated by SDS-PAGE (NuPage 4-12\% Bis-Tris gradient gel) using MES buffer (Invitrogen, CA) and transferred to PVDF membranes. Rabbit antibodies against FIZZ-1 (39626, ABCAM), YM1/2 (a kind gift from Dr. Shioko Kimura, NCI, Maryland), and $\alpha$-tubulin (T5168, Sigma) were used for the westerns. Protein bands were analyzed using Alexa fluor 680 Goat anti-rabbit IgG (A21109, Invitrogen) or IRdye800 anti-mouse IgG (610-132-121, Rockland). Quantification was performed using Odyssey and the data was normalized to $\alpha$-tubulin. The data analysis was performed using unpaired two-tailed $t$-test on Graph-Pad Prism (La Jolla, CA).

\section{Results and discussion}

Whole lung gene expression patterns are altered by developmental age and Scnn $1 b$-Tg expression

Principal Components Analysis (PCA) revealed that age was the primary factor affecting global gene expression in lung specimens (Figure 1a). PC1 (36.5\% of over all variance) separated PND 0 mice from older animals, while PC2 (19.9\% of overall variance) separated PND 3 and 10 from PND 42. Scnn1b-Tg mice clustered tightly with their WT littermates at all ages. By extending the analysis to evaluate PC4 and PC5, the WT mice began to separate from Scnn $1 b$-Tg mice, but only at PND 10 and PND 42, respectively (Additional file 1: Figure S1a).
This pattern was also observed upon hierarchical clustering of a combined set of 4514 differentially expressed genes (DEGs; FDR $\leq 0.05, \mathrm{FC} \geq 2$ ) comparing PND 0 expression values to all other time points for each genotype (Figure 1b; Additional file 2: Results file S1). The heat-map demonstrates that a majority of changes in global gene expression (mainly downregulation) occurred between PND 0 and PND 3, regardless of genotype.

As predicted from the PCA and the hierarchical clustering heat maps, robust differences in gene expression were present in both WT (Table 1) and Scnn $1 b$-Tg (Table 2) mice across development, and the DEGs were qualitatively different among time intervals, consistent with the published reports highlighting the continual postnatal lung development [14] and gene expression profiling of developing murine lungs [30]. The top DEGs up-regulated from PND 0 to PND 3 in WT (Table 1) as well as Scnn1b-Tg (Table 2) mice were largely non-coding RNA species including long, noncoding RNAs and miRNAs. Non-coding RNAs tended to be robustly down-regulated between PND 3 to PND 10. While the specific functions of non-coding RNAs are only now being evaluated, their hypothesized role as master regulators of cell development controlling transcriptional regulatory circuitry is consistent with this finding [31,32].

Interestingly, many of the top up-regulated genes from PND 3 to PND 10 in both WT and Scnn $1 b$-Tg mice are related to goblet cell (mucous cell) function and are frequently associated with Th2 inflammation in mice (Clca3, Chi3l4, Chi3l3, Muc5ac, Muc5b, Tff2) (Tables 1 and 2) $[9,33,34]$. This finding is consistent with the overall Th2 polarization characteristic of early postnatal immunity $[35,36]$ and parallels the wave of goblet cell appearance observed histologically during this time frame [10]. We speculate that these under-appreciated responses observed in developing lung are related to innate defense functions of mucus/mucus clearance during the early neonatal period. The fold-increase for this group of genes was always less in Scnn1b-Tg compared to WT during the PND 3-10 interval. Interestingly, while these genes were later down-regulated in WT mice during the PND 10-42 interval, they continued to be up-regulated further at the later interval in Scnn $1 b$-Tg mice (Tables 1 and 2 and data not shown). Thus, failure to down-regulate these Th2 response-associated genes, e.g., Clca3, Chi3l3, and Chi3l4, in the PND 10-42 interval is a key developmental shift that occurs as a consequence of Scnn $1 b$-Tg expression. Also notable during the PND 3 to PND 10 interval was a large up-regulation of Mmp12 in Scnn1b-Tg mice as compared to WT (Table 2), consistent with the role of Mmp12 as a contributor to the airspace enlargement in this model [23]. 
a



b

Age (PND) $0 \quad 3 \quad 1042 \quad 0 \quad 3 \quad 1042$

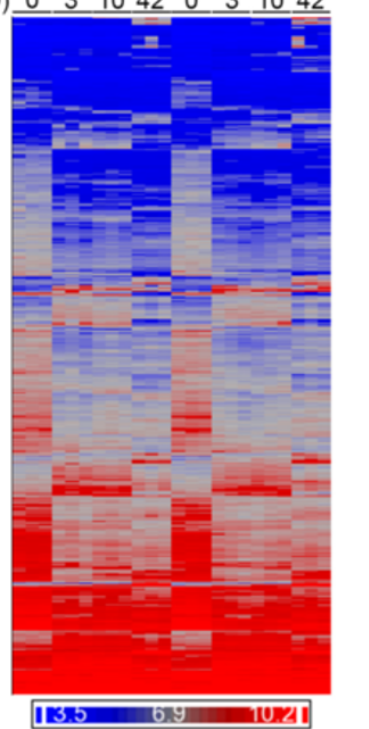

C
Up-regulated
Down-regulated

PND 3 vs PND 0
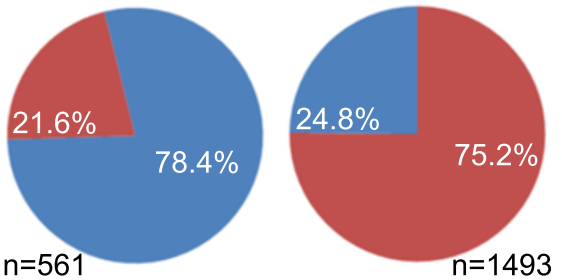

PND10 vs PND 3
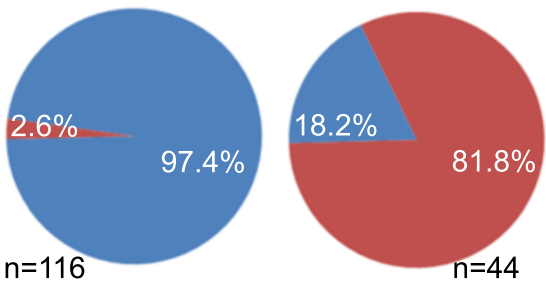

PND 42 vs PND 10
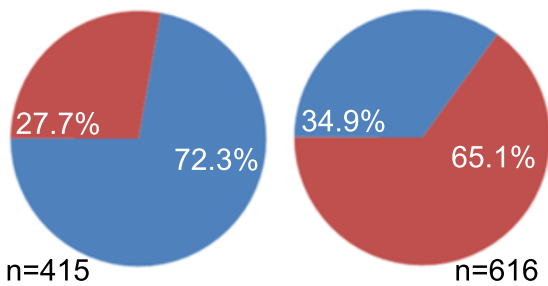

$W T>T g \square W T<T g$

Figure 1 Gene expression patterns in WT and Scnn1b-Tg whole lung. (a) Principal component analysis (PCA) of gene expression from WT and Scnn1b-Tg whole lungs at PND 0, 3, 10, and 42 plotted in two-dimensional space using the first two principal components, which together constitute $55.4 \%$ of the overall variance in this study. Squares $=W T$; Triangles $=S c n n 1 b-T g$. Each symbol represents the results of a single microarray. Each symbol represents a pool of animals as described in the methods. $\mathrm{N}=3$ pools for each age and genotype. Age is designated by color: PND 0 (red), PND 3 (green), PND 10 (blue), and PND 42 (purple). (b) Unsupervised hierarchical clustering of the combined set of differentially expressed genes (DEGs) that survive the filtering criteria (FDR $\leq 0.05$, fold-change $\geq 2$ ) across development (comparing PND 0 to all other time points for each genotype, i.e., WT and Scnn1b-Tg; total genes represented = 4514; Additional file 2: Results file S1). Dark blue indicates lower expression levels and bright red indicates higher expression levels, and each column represents the results of one microarray $N=3$ for each genotype at each age). (c) Pie charts highlighting the shift in expression of developmentally regulated genes due to $S \mathrm{cnn} 1 \mathrm{~b}$-Tg expression. Each row represents a different developmental interval and each pie chart represents the pattern for the genes that are differentially regulated (fold-change $>2.0$; FDR $<0.05$ ) in WT mice. Genes normally up-regulated in WT mice are represented in the left column and genes normally down-regulated are represented in the right column, with the number of gene shown for each piechart. The percentages represent the genes that are either higher or lower (blue and red, respectively) in WT vs Scnn1b-Tg at the later developmental stage represented by the interval.

While evaluation of individual gene-level differences was informative, interpretation of collective expression patterns was aided by Gene Set Enrichment Analysis (GSEA), which identified the top Gene Ontology groups that differed across developmental intervals (Table 3). GSEA analysis revealed that G-protein regulated signaling pathways capable of responding to various stimuli are established early in post-natal development (PND 3 versus
PND 0) for both WT and Scnn1b-Tg mice (Table 3). Upand down-regulated pathways were more similar between the two genotypes at the early (PND 3 versus PND 0) and late (PND 42 versus PND 10) intervals compared to the intermediate PND 10 versus PND 3 interval. The patterns observed in WT mice for the PND 3 to PND 10 interval suggest continued lung development based upon the upregulation of pathways involved with reorganization of the 
Table 1 Developmentally regulated genes in whole lung from WT mice

\begin{tabular}{|c|c|c|c|c|c|c|c|c|}
\hline \multirow{2}{*}{$\begin{array}{l}\text { Gene } \\
\text { Name }\end{array}$} & \multicolumn{2}{|c|}{ Fold change: PND 3 vs 0} & \multirow{2}{*}{$\begin{array}{l}\text { Gene } \\
\text { Name }\end{array}$} & \multicolumn{2}{|c|}{ Fold change: PND 10 vs 3} & \multirow{2}{*}{$\begin{array}{l}\text { Gene } \\
\text { Name }\end{array}$} & \multicolumn{2}{|c|}{ Fold change: PND 42 vs 10} \\
\hline & WT & Scnn $1 b-\mathrm{Tg}$ & & WT & Scnn $1 b-\mathrm{Tg}$ & & WT & Scnn $1 b-\mathrm{Tg}$ \\
\hline \multicolumn{9}{|l|}{ UP-REGULATED } \\
\hline Vaultrc5* & 28.5 & 27.7 & $\mathrm{Clca3}$ & 71.5 & 12.0 & Snord116* & 26.2 & 19.6 \\
\hline Gm22866* & 24.4 & 26.8 & Chi3/4 & 12.9 & 4.6 & Gm10722 & 25.7 & 43.9 \\
\hline Snora16a* & 20.3 & 22.0 & Chi3/3 & 10.1 & 5.2 & Bpifa1 & 23.0 & 7.3 \\
\hline Rnu3a* & 18.4 & 16.6 & Crabp 1 & 8.9 & 5.6 & Inmt & 17.8 & 10.8 \\
\hline Gm26493 & 17.3 & 13.2 & Tff2 & 8.0 & 7.9 & Cyp2b10 & 17.6 & 10.1 \\
\hline Rnu3b1* & 15.7 & 14.7 & Ltbp2 & 6.8 & 3.9 & Gm10800 & 17.6 & 67.7 \\
\hline Gm23444 & 13.8 & 13.3 & Hmen1 & 5.4 & 3.3 & Fmo3 & 14.9 & 6.6 \\
\hline Snord22* & 13.7 & 13.4 & $C 7$ & 5.4 & 7.4 & Lrat & 14.7 & 14.7 \\
\hline Snora69* & 13.3 & 11.9 & Bpifb1 & 4.2 & 3.1 & $C f d$ & 13.9 & 14.4 \\
\hline Rny 1* & 13.1 & 15.6 & Enpp1 & 4.0 & 1.9 & Nrld1 & 13.7 & 14.4 \\
\hline$n-R 5 s 25^{*}$ & 12.4 & 13.7 & Muc5ac & 4.0 & 1.5 & $C 4 b$ & 13.2 & 13.8 \\
\hline Snora23* & 12.4 & 10.5 & $T h c$ & 3.9 & 3.0 & Gm25089* & 11.8 & 9.5 \\
\hline Snord $118^{*}$ & 11.1 & 7.2 & $A 2 m$ & 3.7 & 2.1 & Prelp & 11.6 & 11.6 \\
\hline Gm24616 & 10.9 & 8.4 & Muc5b & 3.7 & 2.0 & Serpina3n & 11.3 & 6.3 \\
\hline Gm23927 & 10.0 & 13.5 & Mir27b* & 3.6 & 1.7 & Mir680-2* & 11.2 & 9.0 \\
\hline \multicolumn{9}{|c|}{ DOWN-REGULATED } \\
\hline $\operatorname{Meg}^{*}$ & -32.1 & -34.3 & Gm26493 & -12.9 & -16 & Tnc & -25.1 & -10 \\
\hline C530030P08Rik & -10.3 & -19 & Snora69* & -9.8 & -9.6 & Egfem 1 & -24 & -18 \\
\hline Zbtb16 & -8.8 & -3.3 & Gm24616 & -8.8 & -12.2 & Prss35 & -18.4 & -9.2 \\
\hline Malat1* & -8.8 & -9.7 & Snord $118^{*}$ & -7.6 & -4.7 & Agt & -14.8 & -9.3 \\
\hline 6720401G13Rik* & -7.9 & -11.7 & Snora34* & -5.1 & -6 & Vcan & -14.4 & -7.5 \\
\hline Mir145 & -6.2 & -11.9 & Olfm4 & -4.8 & -3.9 & Spon2 & -12.7 & -7.6 \\
\hline Atp6r0a4 & -6.2 & -2.2 & Asprv1 & -4.6 & -1.8 & SIc27a6 & -12.7 & -12.6 \\
\hline Adamts 12 & -6 & -3 & Cldn4 & -4.5 & -3.5 & Frem 1 & -12.3 & -6.4 \\
\hline Wnk1 & -5.8 & -9 & Stfa3 & -4.2 & -3.4 & $\mathrm{Clca3}$ & -11 & 11.6 \\
\hline Dlk1 & -5.8 & -4.1 & $H 19^{*}$ & -4.1 & -1.5 & 6330403K07Rik* & -10.1 & -4.8 \\
\hline Tead1 & -5.7 & -5.6 & $\lg f 2$ & -4 & -3.1 & Ccna2 & -9.9 & -7.8 \\
\hline Nfat5 & -5.6 & -7.6 & Agtr2 & -3.6 & -3.2 & Crabpl & -9.7 & -4.8 \\
\hline Cox2O & -5.5 & -7.9 & $5100 a 14$ & -3.4 & -3.9 & $S t f a 2 / 1$ & -9.5 & -8.7 \\
\hline Tfсp2/1 & -5.3 & -3.9 & $G d p d 2$ & -3.2 & -2.6 & Phex & -9.2 & -5.5 \\
\hline Leng8 & -5.2 & -7.1 & Smpx & -3.2 & -1.3 & Chi3/4 & -8.9 & 10.5 \\
\hline
\end{tabular}

Listing of the top 15 developmentally up- and down-regulated genes from whole lung of WT mice between three separate age intervals. The fold-changes for these top 15 genes are shown for both the WT and the Scnn $1 b$-Tg mice.

* Non-coding RNA species.

extracellular matrix, epithelial cell migration, and continued maturation of vessels. During the same interval, downregulation of pathways involved in defense and killing of pathogens suggests the establishment of immune homeostasis in WT mice. Significant development of an adaptive immune response signature occurred during the PND 10 and PND 42 interval in both lines of mice as indicated by up-regulation of GO pathways involving humoral immune responses, lymphocyte immunity, antigen processing, and complement activation.
Scnn $1 b$-Tg mice showed early evidence of inflammatory signaling during the PND 0 to PND 3 interval as indicated by up-regulation of GO inflammatory response and cytokine signaling pathways (Table 3). Up-regulated GO groups related to mitosis at the PND3 to PND 10 interval in Scnn1b-Tg mice point to transgene expression-induced shifts in the mitotic state of the lung. Furthermore, the down-regulation of GO immune defense pathways seen in WT mice during the PND 3 to PND 10 interval was clearly disrupted in the $S c n n 1 b-\mathrm{Tg}$ 
Table 2 Developmentally regulated genes in whole lung from Scnn 1b-Tg mice

\begin{tabular}{|c|c|c|c|c|c|c|c|c|}
\hline \multirow{2}{*}{$\begin{array}{l}\text { Gene } \\
\text { Name }\end{array}$} & \multicolumn{2}{|c|}{ Fold change: PND 3 vs 0} & \multirow{2}{*}{$\begin{array}{l}\text { Gene } \\
\text { Name }\end{array}$} & \multicolumn{2}{|c|}{ Fold change: PND 10 vs 3} & \multirow{2}{*}{$\begin{array}{l}\text { Gene } \\
\text { Name }\end{array}$} & \multicolumn{2}{|c|}{ Fold change: PND 42 vs 10} \\
\hline & Scnn $1 b-\mathrm{Tg}$ & WT & & Scnn $1 b-\mathrm{Tg}$ & WT & & Scnn $1 b-\mathrm{Tg}$ & WT \\
\hline \multicolumn{9}{|l|}{ UP-REGULATED } \\
\hline Vaultrc5* & 27.7 & 28.4 & $\mathrm{Clca3}$ & 12.0 & 71.4 & Gm10800 & 67.8 & 17.6 \\
\hline Gm22866* & 26.8 & 24.4 & Mmp12 & 11.5 & 1.9 & Gm10722 & 43.9 & 25.8 \\
\hline Snora16a* & 22.0 & 20.3 & Tff2 & 7.9 & 8.0 & Snord $116^{*}$ & 19.6 & 26.2 \\
\hline Rnu3a* & 16.6 & 18.4 & $C 7$ & 7.4 & 5.4 & Lrat & 14.7 & 14.8 \\
\hline Rny $1^{*}$ & 15.6 & 13.1 & Crabp 1 & 5.7 & 8.9 & Nrld1 & 14.4 & 13.8 \\
\hline Rnu3b1* & 14.7 & 15.7 & Chi3/3 & 5.2 & 10.1 & $C f d$ & 14.4 & 13.9 \\
\hline$n-R 5 s 25^{*}$ & 13.6 & 12.4 & Chi3/4 & 4.6 & 13.0 & $C 4 b$ & 13.8 & 13.2 \\
\hline Gm23927* & 13.5 & 10.0 & $\mathrm{H} 2-\mathrm{Aa}$ & 4.6 & 2.6 & Chi3/3 & 12.2 & 1.4 \\
\hline Snord22* & 13.4 & 13.7 & $H 2-A b 1$ & 4.3 & 2.8 & Car3 & 11.9 & 10.6 \\
\hline Gm23444 & 13.3 & 13.9 & Ltbp2 & 3.9 & 6.8 & Prelp & 11.6 & 11.6 \\
\hline Gm26493 & 13.2 & 17.3 & $4833424015 R i k$ & 3.8 & 2.7 & $\mathrm{Clca3}$ & 11.6 & -10.9 \\
\hline Snora69* & 11.9 & 13.3 & $C d 74$ & 3.7 & 2.3 & Inmt & 10.8 & 17.8 \\
\hline Snora23* & 10.5 & 12.4 & $\mathrm{H} 2-E b 1$ & 3.7 & 2.6 & Chi3/4 & 10.5 & -8.9 \\
\hline Snord $35 b^{*}$ & 9.6 & 7.9 & Aard & 3.6 & 1.9 & Cxcl14 & 10.2 & 8.0 \\
\hline Snora34* & 9.3 & 9.6 & Cdkn2c & 3.4 & 3.3 & Speer8-ps1 & 10.2 & 8.7 \\
\hline \multicolumn{9}{|c|}{ DOWN-REGULATED } \\
\hline $\operatorname{Meg}^{*}$ & -34.3 & -32.1 & Gm26493* & -16.0 & -12.3 & Egfem 1 & -18.0 & -24.0 \\
\hline C530030P08Rik & -19.0 & -10.3 & Gm24616* & -12.2 & -8.8 & $H 19^{*}$ & -13.9 & -5.5 \\
\hline Mir145* & -11.9 & -6.2 & Snora69* & -9.6 & -9.8 & Slc27a6 & -12.6 & -12.7 \\
\hline 6720401G13Rik & -11.7 & -7.9 & Snora23* & -9.4 & -5.5 & The & -10.0 & -25.1 \\
\hline Malat1* & -9.7 & -8.8 & Snora34* & -6.0 & -5.1 & Capn6 & -9.8 & -7.6 \\
\hline Gm7265 & -9.5 & -4.5 & Gm10722 & -4.7 & -1.7 & Agt & -9.3 & -14.8 \\
\hline Wnk1 & -9.0 & -5.8 & S100a14 & -3.9 & -3.4 & Prss35 & -9.2 & -18.4 \\
\hline Mir23b* & -8.6 & -5.1 & Gm22806* & -3.6 & -3.1 & Pbk & -8.8 & -3.7 \\
\hline Cox20 & -7.9 & -5.5 & Rnulb1* & -3.6 & -2.4 & Stfa2l1 & -8.7 & -9.5 \\
\hline Nfat5 & -7.6 & -5.6 & Cldn4 & -3.5 & -4.5 & Hist1h2ab & -8.6 & -7.3 \\
\hline Gm25831* & -7.2 & -2.6 & Agtr2 & -3.2 & -3.6 & Nuf2 & -8.3 & -5.6 \\
\hline Leng8 & -7.1 & -5.2 & $\lg f 2$ & -3.1 & -4.0 & Ccnb2 & -7.9 & -5.6 \\
\hline $\mathrm{Fb} \times 17$ & -5.9 & -3.4 & Upk3a & -3.1 & -2.4 & Ccna2 & -7.8 & -9.9 \\
\hline B930095G15Rik & -5.7 & -3.7 & Cst8 & -2.8 & -2.3 & Spon2 & -7.6 & -12.7 \\
\hline Srrm2 & -5.7 & -4.2 & Liph & -2.7 & -1.9 & Vean & -7.5 & -14.4 \\
\hline
\end{tabular}

Top 15 developmentally up- and down-regulated genes from whole lung of Scnn $1 b$-Tg mice between three separate age intervals. The fold-changes for these top 15 genes are shown for both Scnn $1 b$-Tg and the WT mice.

* Non-coding RNA species.

line. Indeed, closer evaluation identified a pattern whereby expression of the transgene altered normal developmental processes in subtle, but measureable, ways that were not immediately apparent (Figure 1c). The absolute expression level of developmentally up-regulated genes was consistently less in the Scnn $1 b$-Tg mice compared to WT, and at PND 10, a striking $97 \%$ of these genes had lower expression in Scnn1b-Tg mice compared to WT (Figure 1c). An inverse phenomenon held true for genes that were developmentally down-regulated in WT mice, which trended towards higher expression in Scnn $1 b-\mathrm{Tg}$ mice. While the fold-changes between Scnn1b-Tg and WT for these genes were generally subtle, the consistency of the pattern leads to the conclusion that expression of the transgene, and/or its resultant pathology, alters developmental pathways. The presence of an inflammatory stimulus in the context of developing lung tissue during this early post-natal timeframe in this model is highly relevant to human bronchopulmonary dysplasia (BPD), whereby the under-developed lungs of premature infants 
Table 3 Developmentally regulated Gene Ontology groups for whole lung in WT and Scnn 1b-Tg mice

\begin{tabular}{|c|c|c|c|c|c|}
\hline \multicolumn{2}{|c|}{ PND 3 versus PND 0} & \multicolumn{2}{|c|}{ PND 10 versus PND3 } & \multicolumn{2}{|c|}{ PND 42 versus PND 10} \\
\hline WT & Scnn $1 b-\mathrm{Tg}$ & WT & Scnn $1 b-\mathrm{Tg}$ & WT & Scnn $1 b-\mathrm{Tg}$ \\
\hline \multicolumn{6}{|l|}{ UP-REGULATED } \\
\hline GO:0007608 & GO:0007608 & GO:0030198 & GO:0007067 & GO:0006959 & GO:0006959 \\
\hline $\begin{array}{l}\text { Sensory perception } \\
\text { of smell }\end{array}$ & $\begin{array}{l}\text { Sensory perception } \\
\text { of smell }\end{array}$ & $\begin{array}{l}\text { Extracellular matrix } \\
\text { organization }\end{array}$ & Mitosis & $\begin{array}{l}\text { Humoral immune } \\
\text { response }\end{array}$ & $\begin{array}{l}\text { Humoral immune } \\
\text { response }\end{array}$ \\
\hline GO:0007606 & GO:0007606 & GO:0043062 & GO:0000280 & GO:0048002 & GO:0019882 \\
\hline $\begin{array}{l}\text { Sensory perception } \\
\text { of chemical stimulus }\end{array}$ & $\begin{array}{l}\text { Sensory perception } \\
\text { of chemical stimulus }\end{array}$ & $\begin{array}{l}\text { Extracellular structure } \\
\text { organization }\end{array}$ & Nuclear division & $\begin{array}{l}\text { Antigen processing and } \\
\text { presentation of peptide } \\
\text { antigen }\end{array}$ & $\begin{array}{l}\text { Antigen processing and } \\
\text { presentation }\end{array}$ \\
\hline GO:0007600 & GO:0007600 & GO:0021988 & GO:0007059 & GO:0002455 & GO:0002253 \\
\hline Sensory perception & Sensory perception & $\begin{array}{l}\text { Olfactory lobe } \\
\text { development }\end{array}$ & $\begin{array}{l}\text { Chromosome } \\
\text { segregation }\end{array}$ & $\begin{array}{l}\text { Humoral immune } \\
\text { response mediated by } \\
\text { circulating } \\
\text { immunoglobulin }\end{array}$ & $\begin{array}{l}\text { Activation of immune } \\
\text { response }\end{array}$ \\
\hline GO:0019236 & GO:0019236 & GO:0030199 & GO:0048285 & GO:0072376 & GO:0050778 \\
\hline $\begin{array}{l}\text { Response to } \\
\text { pheromone }\end{array}$ & $\begin{array}{l}\text { Response to } \\
\text { pheromone }\end{array}$ & $\begin{array}{l}\text { Collagen fibril } \\
\text { organization }\end{array}$ & $\begin{array}{l}\text { Organelle } \\
\text { fission }\end{array}$ & $\begin{array}{l}\text { Protein activation } \\
\text { cascade }\end{array}$ & $\begin{array}{l}\text { Positive regulation of } \\
\text { immune response }\end{array}$ \\
\hline GO:0009263 & GO:0007186 & GO:0031589 & GO:0051301 & GO:0006956 & GO:0048002 \\
\hline $\begin{array}{l}\text { Deoxyribonucleotide } \\
\text { biosynthetic process }\end{array}$ & $\begin{array}{l}\text { G-protein coupled } \\
\text { receptor signaling } \\
\text { pathway }\end{array}$ & Cell-substrate adhesion & Cell division & Complement activation & $\begin{array}{c}\text { Antigen processing and } \\
\text { presentation of peptide } \\
\text { antigen }\end{array}$ \\
\hline GO:0007186 & GO:0002861 & GO:0071526 & GO:0000278 & GO:0002474 & GO:0072376 \\
\hline $\begin{array}{l}\text { G-protein coupled } \\
\text { receptor signaling } \\
\text { pathway }\end{array}$ & $\begin{array}{l}\text { Regulation of } \\
\text { inflammatory } \\
\text { response to antigenic } \\
\text { stimulus }\end{array}$ & $\begin{array}{l}\text { Semaphorin-plexin } \\
\text { signaling pathway }\end{array}$ & $\begin{array}{l}\text { Mitotic cell } \\
\text { cycle }\end{array}$ & $\begin{array}{l}\text { Antigen processing and } \\
\text { presentation of peptide } \\
\text { antigen via MCH class I }\end{array}$ & $\begin{array}{l}\text { Protein activation } \\
\text { cascade }\end{array}$ \\
\hline GO:0033108 & GO:0002675 & GO:0007155 & GO:0007051 & GO:0019882 & GO:0006956 \\
\hline $\begin{array}{l}\text { Mitochondrial } \\
\text { respiratory chain } \\
\text { complex assembly }\end{array}$ & $\begin{array}{l}\text { Positive regulation of } \\
\text { acute inflammatory } \\
\text { response }\end{array}$ & Cell adhesion & $\begin{array}{l}\text { Spindle } \\
\text { organization }\end{array}$ & $\begin{array}{l}\text { Antigen processing and } \\
\text { presentation }\end{array}$ & Complement activation \\
\hline GO:0009262 & GO:0050877 & GO:0002040 & GO:0031023 & GO:0006958 & GO:0002455 \\
\hline $\begin{array}{l}\text { Deoxyribonucleotide } \\
\text { metabolic process }\end{array}$ & $\begin{array}{l}\text { Neurological system } \\
\text { process }\end{array}$ & Sprouting angiogenesis & $\begin{array}{l}\text { Microtubule } \\
\text { organizing } \\
\text { center } \\
\text { organization }\end{array}$ & $\begin{array}{l}\text { Complement activation } \\
\text { classical pathway }\end{array}$ & $\begin{array}{l}\text { Humoral immune } \\
\text { response mediated by } \\
\text { circulating } \\
\text { immunoglobulin }\end{array}$ \\
\hline GO:0006270 & GO:0050715 & GO:0090132 & GO:0007052 & GO:0002449 & GO:0002684 \\
\hline $\begin{array}{l}\text { DNA replication } \\
\text { initiation }\end{array}$ & $\begin{array}{l}\text { Positive regulation of } \\
\text { cytokine secretion }\end{array}$ & Epithelial migration & $\begin{array}{l}\text { Mitotic spindle } \\
\text { organization }\end{array}$ & $\begin{array}{l}\text { Lymphocyte mediated } \\
\text { immunity }\end{array}$ & $\begin{array}{l}\text { Positive regulation of } \\
\text { immune system process }\end{array}$ \\
\hline GO:0032981 & GO:0046146 & GO:0021772 & GO:0051297 & GO:0017144 & GO:0002478 \\
\hline $\begin{array}{l}\text { Mitochondrial } \\
\text { respiratory chain } \\
\text { complex I assembly }\end{array}$ & $\begin{array}{l}\text { Tetrahydrobiopterin } \\
\text { metabolic process }\end{array}$ & $\begin{array}{l}\text { Olfactory bulb } \\
\text { development }\end{array}$ & $\begin{array}{l}\text { Centrosome } \\
\text { organization }\end{array}$ & Drug metabolic processes & $\begin{array}{l}\text { Antigen processing and } \\
\text { presentation of } \\
\text { exogenous peptide } \\
\text { antigen }\end{array}$ \\
\hline \multicolumn{6}{|l|}{ DOWN-REGULATED } \\
\hline GO:0007265 & GO:0051056 & GO:0044364 & GO:0008299 & GO:0007067 & GO:0007067 \\
\hline $\begin{array}{l}\text { Ras protein signal } \\
\text { transduction }\end{array}$ & $\begin{array}{l}\text { Regulation of small } \\
\text { GTPase mediated } \\
\text { signal transduction }\end{array}$ & $\begin{array}{l}\text { Disruption of cells of } \\
\text { other organism }\end{array}$ & $\begin{array}{l}\text { Isoprenoid } \\
\text { biosynthetic } \\
\text { process }\end{array}$ & Mitosis & Mitosis \\
\hline GO:0051056 & GO:0007265 & GO:0031640 & NONE* & GO:0000280 & GO:0000280 \\
\hline $\begin{array}{l}\text { Regulation of small } \\
\text { GTPase mediated } \\
\text { signal transduction }\end{array}$ & $\begin{array}{l}\text { Ras protein signal } \\
\text { transduction }\end{array}$ & $\begin{array}{l}\text { Killing of cells of other } \\
\text { organism }\end{array}$ & & Nuclear division & Nuclear division \\
\hline 0046578 & GO:0046578 & GO:0051818 & & GO:0048285 & GO:0048285 \\
\hline
\end{tabular}


Table 3 Developmentally regulated Gene Ontology groups for whole lung in WT and Scnn1b-Tg mice (Continued)

\begin{tabular}{|c|c|c|c|c|}
\hline $\begin{array}{l}\text { Regulation of Ras } \\
\text { protein signal } \\
\text { transduction }\end{array}$ & $\begin{array}{l}\text { Regulation of Ras } \\
\text { protein signal } \\
\text { transduction }\end{array}$ & $\begin{array}{l}\text { Disruption of cells of } \\
\text { other organism involved } \\
\text { in symbiotic interaction }\end{array}$ & Organelle fission & Organelle fission \\
\hline GO:0007266 & GO:0007266 & GO:0051883 & GO:0007059 & GO:0007059 \\
\hline $\begin{array}{l}\text { Rho protein signal } \\
\text { transduction }\end{array}$ & $\begin{array}{l}\text { Rho protein signal } \\
\text { transduction }\end{array}$ & $\begin{array}{l}\text { Killing of cells in other } \\
\text { organism involved in } \\
\text { symbiotic interaction }\end{array}$ & Chromosome segregation & $\begin{array}{l}\text { Chromosome } \\
\text { segregation }\end{array}$ \\
\hline GO:0035295 & GO:0016568 & GO:0006953 & GO:0051301 & GO:0051301 \\
\hline Tube development & $\begin{array}{l}\text { Chromatin } \\
\text { modification }\end{array}$ & Acute phase response & Cell division & Cell division \\
\hline GO:0010631 & GO:0016569 & GO:0050829 & GO:0006323 & GO:0000278 \\
\hline $\begin{array}{l}\text { Epithelial cell } \\
\text { migration }\end{array}$ & $\begin{array}{l}\text { Covalent chromatin } \\
\text { modification }\end{array}$ & $\begin{array}{l}\text { Defense response to } \\
\text { Gram-negative bacterium }\end{array}$ & DNA packaging & Mitotic cell cycle \\
\hline GO:0090130 & GO:0016570 & GO:0002886 & GO:0000278 & GO:0006323 \\
\hline Tissue migration & Histone modification & $\begin{array}{l}\text { Regulation of myeloid } \\
\text { leukocyte mediated } \\
\text { immunity }\end{array}$ & Mitotic cell cycle & DNA packaging \\
\hline GO:0090132 & GO:0007507 & GO:0051873 & GO:0000819 & GO:0071103 \\
\hline Epithelium migration & Heart development & $\begin{array}{l}\text { Killing by host of } \\
\text { symbiont cells }\end{array}$ & $\begin{array}{l}\text { Sister chromatid } \\
\text { segregation }\end{array}$ & $\begin{array}{c}\text { DNA conformation } \\
\text { change }\end{array}$ \\
\hline GO:0060562 & GO:0046777 & GO:0051852 & GO:0000070 & GO:0022402 \\
\hline $\begin{array}{l}\text { Epithelial tube } \\
\text { morphogenesis }\end{array}$ & $\begin{array}{c}\text { Protein } \\
\text { autophosphorylation }\end{array}$ & $\begin{array}{l}\text { Disruption by host of } \\
\text { symbiont cells }\end{array}$ & $\begin{array}{l}\text { Mitotic sister chromatid } \\
\text { segregation }\end{array}$ & Cell cycle process \\
\hline GO:0035239 & GO:0072358 & GO:0031424 & GO:0071103 & GO:0034470 \\
\hline Tube morphogenesis & $\begin{array}{c}\text { Cardiovascular system } \\
\text { development }\end{array}$ & Keratinization & $\begin{array}{l}\text { DNA conformation } \\
\text { change }\end{array}$ & ncRNA processing \\
\hline
\end{tabular}

Top ten developmentally up- and down-regulated Gene Ontology groups for whole lung in WT and Scnn $1 b$-Tg mice between the specified developmental intervals. Gene Ontology groups in common between the WT and Scnn $1 b$-Tg line are highlighted by bolded and italicized text. Groups are only listed if FDR <0.1. *NONE indicates that no additional groups met the significance threshold FDR<0.1.

are subjected to inflammatory challenges leading to long-term consequences for lung health [37].

We next conducted analyses whereby the specific genes and pathways altered by transgene expression at the four time points were determined (Figure 2; Tables 3 and 4; Additional file 3: Table S1). Despite the robust pathological findings consistently observed in Scnn $1 b$-Tg mice after PND 3 (neutrophilia, macrophage activation, airspace enlargement, mucus plugging $[9,12])$, overexpression of the $S c n n 1 b$ transgene in the club cells produced surprisingly few significant (FDR $\leq 0.05, F C \geq 2$ ) gene expression changes as evaluated from whole lung RNA (Additional file 2: Results file S1): only 84 combined DEGs (3, 2, 16, and 72 , at PND $0,3,10$, and 42 , respectively), were identified between Scnn1b-Tg and WT mice (Figure 2; Table 4). As expected, the $S c n n 1 b$ transgene was up-regulated at all time-points (Table 4). A majority of DEGs were upregulated only at PND 42, with only a few genes (for example: Scgb1c1, Cyp2a4, Fabp1) robustly down-regulated, and very few genes differentially expressed at PND 0 and PND 3 time points. The down-regulated group at PND 10 included genes (Muc5ac, Clca3, Slc26a4, and Chi3l4), associated with Th2 inflammatory processes and mucous cell functions, as described above (Tables 1 and Table 2).
Since $S c n n 1 b$-Tg expression is driven by the promoter for Scgb1a1 gene (encoding club cell secretory protein), and because club cells are transiently necrotic during early postnatal life [9], we looked specifically at Scgb1a1 gene expression as a surrogate for club cell function. Levels of Scgb1a1 were modestly reduced in $S c n n 1 b$-tg mice compared to WT at PND 0,3 and 10 [foldchange -1.9 (p-value 0.009), -1.7 (p-value 0.02), -1.5 (p-value 0.06), respectively], but not at PND 42 [foldchange -1.04 ( $\mathrm{p}$-value 0.82 )]. These data indicate that normal club cell function was disrupted during early post-natal life as a result of transgene expression, as expected from histological findings, and that disruption of club cell function may be contributing to early inflammatory processes [38]. However, in the chronic state of muco-obstruction observed at PND 42, club cell function as measured by Scgb1a1 expression was normal.

Evaluation of Gene Ontology terms associated with the differentially regulated genes was only moderately informative, since the genes belonged to multiple annotation categories that only rarely overlapped (Additional file 3: Table S1). However, after a review of the literature, most of the DEGs at PND 42, i.e., when chronic disease is firmly established, fell into expected functional 


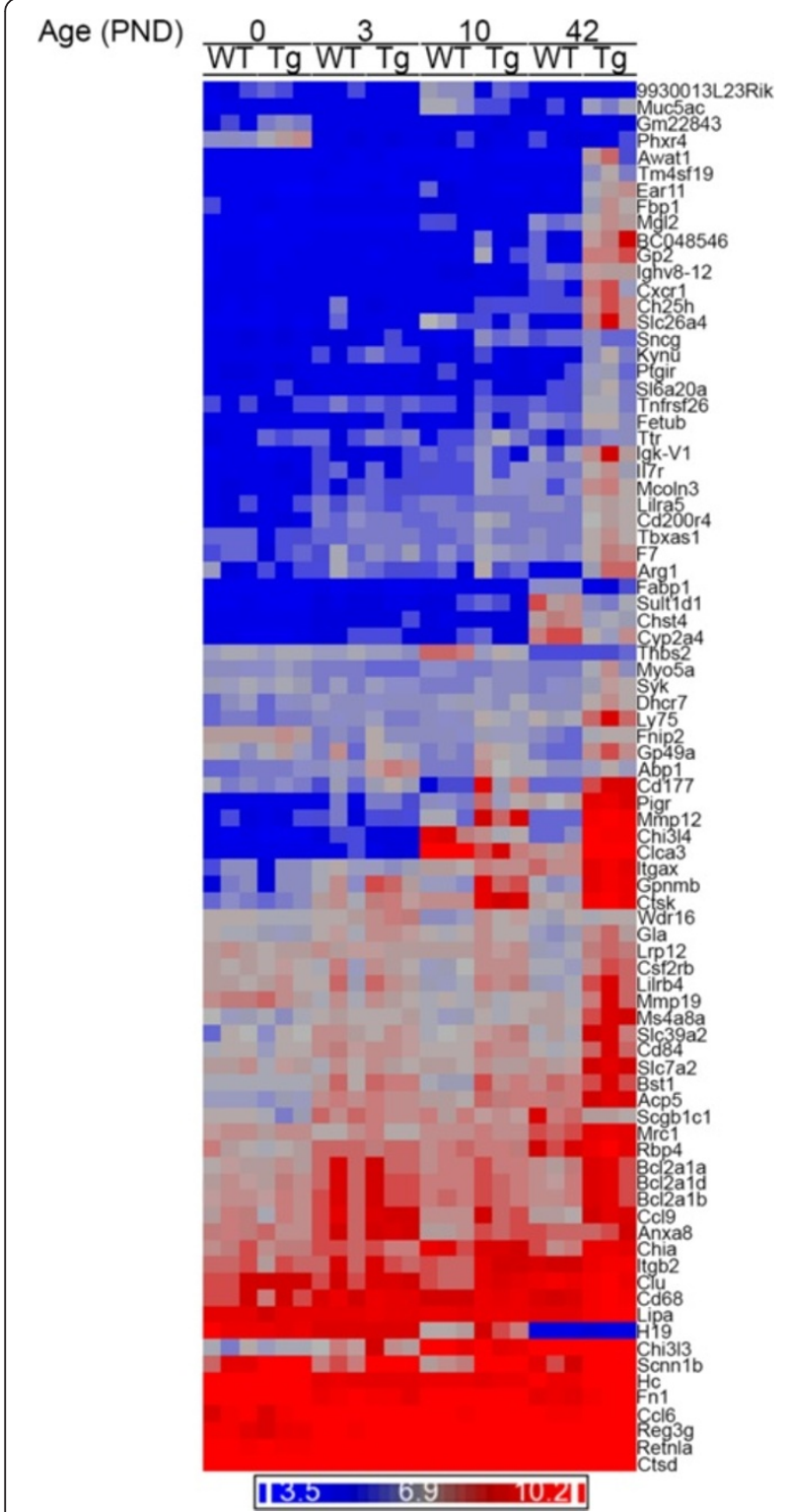

Figure 2 Differential expression of genes in Scnn $1 b$-Tg lungs compared to WT. Unsupervised hierarchical clustering of the combined set of DEGs that survive the filtering criteria (FDR $\leq 0.05$, fold-change 2 2) for WT versus Scnn 1b-Tg for any time point; total genes represented $=84$ (Additional file 2: Results file S1). Dark blue indicates lower expression levels and bright red indicates higher expression levels and each column represents the results of one microarray ( $n=3$ pools for each time point and genotype). DEGs appearing more than once reflect alternative probeset annotations on the Affymetrix microarrays. Scnn $1 b$ and Ttr differential gene expression reflects the overexpression from the transgenic construct used to generate the Scnn 1b-Tg mice [9].

categories, e.g., genes broadly related to lung inflammatory processes (Itgb2, Kynu, Ptgir), neutrophil influx (Bst1, Cd177, Cxcr1), activation of adaptive immunity (Cd84, Ch25h, Gla, Il7r, Mmp19), dendritic cells (Itgax, Ly75); macrophages (Bcl2a1, Ccl6, Ccl9, Cd68, Ctsk,
Ch25h, Gpnmb, Hc, Lilrb4) or epithelial responses to stimuli (Clca3, Ctsd, Gp2, Muc5ac, Pigr, Slc26a4). A significant number of the DEGs were associated with classic Th2 inflammatory responses (Ccl6, Chia, Chi3l4, Clca3, Ear11, F7, Itgax, Slc26a4, Tbxas1) and alternative (M2) macrophage polarization (Retnla, Arg1, Chi3l3, Chi3l4, Ch25h, Lipa, Mgl2, Mmp12, Mrc1, Tbxas1) (Table 4 and Additional file 3: Table S1).

Analyses of GSEA pathways differentially expressed between WT and Scnn1b-Tg mice at the different time points confirmed up-regulation of inflammatory responses starting at PND 10 (Additional file 1: Figure S2; Additional file 4: Results file S2; Additional file 5: Results file S3) and revealed novel responses associated with the establishment of obstructive lung disease, such as up-regulation of GO cilia-specific pathways at PND 10, alterations in tissue organization and development (pathways upregulated at PND 0 and down-regulated at PND 3) and possible disturbances in the establishment of lung immune homeostasis (pathways down-regulated at PND 0) (Table 5). By PND 42, there were no down-regulated pathways that met the significance threshold.

Overall, these data suggest that defective airway mucus clearance due to Scnn1b-Tg overexpression, although originated in a relatively small compartment, i.e., the airway epithelia, which comprises less than $2 \%$ of the total lung surface area, can lead to transcriptional modifications that affect other lung compartments and cell populations, e.g., parenchymal and myeloid lineages, which are strong enough to be detected in whole lung preparations. However, the relative dearth of robust gene-level signatures, especially at the earlier time points, suggested that evaluating gene expression in purified cell populations would be informative. Due to the robust morphological activation of macrophages in the Scnn1b-Tg mice, the tendency for genes involved in macrophage function to be up-regulated in whole lung (Additional file 3: Table S1), and the importance of this cell type in lung disease pathogenesis, we continued our studies by evaluating gene expression in purified pulmonary macrophages.

\section{Macrophage DEGs between Scnn1b-Tg and WT are robust and dynamic}

We hypothesized that defective mucus clearance would alter lung macrophage gene expression and, consequently, we studied purified BAL macrophages from WT and Scnn1b-Tg mice at the previously utilized developmental stages. Furthermore, to evaluate the contribution of lung bacterial infections, the gene expression profiles of lung macrophages purified from germ-free (GF) Scnn1b-Tg and WT littermates at PND 42 were also studied. In addition to macrophages, the harvested BAL preparations includes lymphocytes, eosinophils, and neutrophils, with the 
Table 4 Differentially expressed genes between WT and Scnn 1b-Tg whole lungs

\begin{tabular}{|c|c|c|c|c|c|c|c|c|}
\hline \multirow{2}{*}{$\begin{array}{l}\text { Gene } \\
\text { Name }\end{array}$} & \multicolumn{2}{|c|}{ PND 0} & \multicolumn{2}{|c|}{ PND 3} & \multicolumn{2}{|c|}{ PND 10} & \multicolumn{2}{|c|}{ PND 42} \\
\hline & Fold- Change & FDR $p$-value & Fold-Change & FDR $p$-value & Fold-Change & FDR $p$-value & Fold-Change & FDR $p$-value \\
\hline Scnn1b & 11.7 & 8.47E-05 & 14.8 & $2.23 E-05$ & 14.0 & $3.10 E-05$ & 10.4 & $2.38 E-05$ \\
\hline Ttr & 1.5 & & 1.4 & & 2.2 & $1.98 E-02$ & 1.8 & \\
\hline 9930013L23Rik & 1.2 & & -1.2 & & -2.2 & 4.20E-02 & 1.2 & \\
\hline Thbs2 & -1.0 & & -1.1 & & -2.6 & $6.25 E-05$ & 1.1 & \\
\hline Fabpl & -1.0 & & -1.1 & & -1.1 & & -2.1 & $3.69 E-04$ \\
\hline Chst4 & 1.1 & & 1.0 & & 1.1 & & -2.1 & $1.35 E-04$ \\
\hline Scgblcl & -1.5 & & -1.2 & & -1.2 & & -2.3 & 4.87E-02 \\
\hline Cyp2a4 & -1.0 & & 1.1 & & 1.1 & & -2.4 & $1.91 E-02$ \\
\hline Sult1d1 & -1.1 & & -1.1 & & 1.1 & & -2.8 & $9.46 E-03$ \\
\hline Chi3/4 & -1.1 & & -1.1 & & -3.1 & $5.78 E-02$ & 30.1 & 5.77E-07 \\
\hline $\mathrm{Clca3}$ & -1.0 & & 1.0 & & -5.8 & $6.25 E-05$ & 21.9 & 4.37E-08 \\
\hline Slc26a4 & -1.1 & & -1.2 & & -2.0 & $4.26 E-01$ & 10.3 & 7.47E-05 \\
\hline Muc5ac & 1.0 & & 1.1 & & -2.6 & $1.23 E-02$ & 2.6 & $2.34 E-03$ \\
\hline Phxr4 & 2.2 & $3.64 E-02$ & -1.0 & & -1.1 & & 1.0 & \\
\hline Gm22843 & 2.1 & $2.67 E-02$ & 1.0 & & 1.0 & & -1.0 & \\
\hline Abpl (Aoc1) & 1.2 & & 2.8 & $2.41 E-02$ & 2.3 & $1.66 \mathrm{E}-02$ & 1.1 & \\
\hline Gpnmb & 1.1 & & 2.1 & 7.69E-01 & 5.5 & $5.45 \mathrm{E}-02$ & 13.4 & $7.53 E-04$ \\
\hline Bst1 & -1.0 & & 1.4 & & 2.8 & $2.02 \mathrm{E}-02$ & 1.6 & \\
\hline Sncg & 1.1 & & -1.0 & & 2.4 & $1.39 E-02$ & 1.2 & \\
\hline Wdr16 & -1.2 & & 1.6 & & 2.1 & $1.23 E-02$ & 1.2 & \\
\hline Anxa8 & -1.1 & & 1.3 & & 2.1 & $1.41 \mathrm{E}-02$ & 1.1 & \\
\hline $\mathrm{Clu}$ & 1.1 & & 1.4 & & 2.1 & $1.40 \mathrm{E}-02$ & 1.1 & \\
\hline$H 19^{*}$ & -1.3 & & -1.0 & & 2.6 & $1.46 \mathrm{E}-02$ & 1.0 & \\
\hline Mmp12 & -1.0 & & -1.1 & & 5.4 & $4.53 E-03$ & 34.8 & $2.96 E-07$ \\
\hline Cd177 & -1.2 & & 1.8 & & 6.6 & $2.69 E-02$ & 11.3 & $1.52 E-03$ \\
\hline Ctsk & 1.0 & & 1.4 & & 2.7 & 1.41E-02 & 9.5 & 1.19E-06 \\
\hline Pigr & 1.1 & & 1.5 & & 2.3 & $2.92 E-01$ & 4.9 & $3.40 E-03$ \\
\hline Gp49a & 1.1 & & 1.2 & & 2.3 & $4.63 E-01$ & 4.8 & $1.94 E-02$ \\
\hline Lilrb4 & 1.1 & & 1.3 & & 2.4 & $3.56 E-01$ & 4.2 & $1.82 E-02$ \\
\hline $\mathrm{Ccl} 9$ & -1.2 & & 1.0 & & 2.0 & $5.04 E-01$ & 3.9 & $1.79 E-02$ \\
\hline Mcoln3 & -1.0 & & 1.1 & & 2.0 & $1.67 E-01$ & 3.4 & $2.13 E-03$ \\
\hline $\mathrm{Cd} 68$ & -1.1 & & 1.3 & & 2.1 & $1.14 E-01$ & 2.8 & $6.81 E-03$ \\
\hline Gp2 & -1.0 & & -1.0 & & 1.8 & & 9.9 & $2.63 E-04$ \\
\hline $\operatorname{Arg} 1$ & -1.2 & & -1.3 & & 1.7 & & 8.9 & $6.84 E-03$ \\
\hline BC048546 & -1.1 & & 1.1 & & 1.8 & & 7.5 & 7.47E-05 \\
\hline Ear11 & -1.1 & & 1.0 & & -1.5 & & 7.2 & 4.73E-06 \\
\hline Awat1 & 1.0 & & 1.0 & & 1.0 & & 6.6 & $3.59 E-03$ \\
\hline Ch25h & -1.0 & & -1.2 & & 1.4 & & 6.2 & 1.30E-04 \\
\hline Chi3/3 & 1.1 & & 1.3 & & -1.5 & & 5.8 & $9.46 E-03$ \\
\hline Cxcr 1 & 1.0 & & -1.0 & & 1.2 & & 5.7 & $9.66 E-04$ \\
\hline Bcl2ald & -1.2 & & -1.1 & & -1.3 & & 5.4 & 1.91E-02 \\
\hline Retnla (Fizz1) & -1.4 & & -1.2 & & -1.9 & & 5.0 & 4.84E-02 \\
\hline $\operatorname{ltgax}$ & -1.1 & & -1.3 & & 1.6 & & 4.4 & $4.59 E-03$ \\
\hline
\end{tabular}


Table 4 Differentially expressed genes between WT and Scnn 1b-Tg whole lungs (Continued)

\begin{tabular}{|c|c|c|c|c|c|}
\hline $\operatorname{lgk}-V 1$ & -1.0 & -1.2 & 1.0 & 3.9 & $2.64 E-02$ \\
\hline Fbp 1 & -1.2 & -1.1 & -1.4 & 3.8 & 8.44E-05 \\
\hline Chia & -1.1 & -1.2 & -1.3 & 3.5 & $9.69 E-03$ \\
\hline $\mathrm{Ccl} 6$ & -1.0 & 1.3 & 1.2 & 3.5 & 4.13E-02 \\
\hline$L y 75$ & 1.0 & -1.1 & 1.6 & 3.3 & 7.53E-04 \\
\hline Ighv8-12 & 1.1 & -1.1 & -1.1 & 3.2 & 1.62E-06 \\
\hline Tm4sfig & 1.0 & 1.0 & 1.1 & 3.2 & 3.91E-05 \\
\hline Slc39a2 & 1.1 & -1.1 & 1.7 & 3.2 & $3.42 E-02$ \\
\hline Kynu & 1.0 & 1.2 & 1.1 & 3.0 & $5.52 E-03$ \\
\hline Ms4a8a & -1.0 & -1.0 & 1.3 & 3.0 & 4. $18 E-04$ \\
\hline $\operatorname{Reg} 3 g$ & -1.3 & 1.7 & 1.7 & 3.0 & 4.08E-02 \\
\hline Csfarb & -1.1 & 1.3 & 1.9 & 3.0 & $2.08 E-02$ \\
\hline Mgl2 & -1.0 & -1.0 & -1.6 & 2.9 & 4.19E-04 \\
\hline Slc7a2 & -1.1 & 1.2 & 1.1 & 2.9 & $9.46 E-03$ \\
\hline Cd84 & -1.1 & -1.0 & 1.4 & 2.9 & $1.53 E-03$ \\
\hline$F 7$ & -1.2 & 1.3 & 1.7 & 2.9 & $1.94 E-02$ \\
\hline Gla & -1.2 & 1.4 & 1.3 & 2.7 & 7.90E-03 \\
\hline $\operatorname{ltg} b 2$ & -1.3 & 1.1 & 1.7 & 2.7 & 1.66E-02 \\
\hline Mmp19 & -1.0 & 1.3 & 1.1 & 2.6 & 3.25E-02 \\
\hline Tbxas 1 & -1.3 & 1.1 & 1.2 & 2.6 & $2.76 E-03$ \\
\hline Lrp12 & -1.1 & -1.1 & 1.2 & 2.6 & $2.38 E-05$ \\
\hline Bcl2ala & 1.1 & -1.1 & 1.2 & 2.6 & 1.27E-02 \\
\hline Slc6a20a & 1.1 & -1.0 & 1.2 & 2.5 & $6.17 E-03$ \\
\hline Cd200r4 & -1.1 & -1.0 & 1.5 & 2.5 & $1.52 E-03$ \\
\hline Rbp4 & -1.4 & -1.1 & -1.0 & 2.4 & $1.94 E-02$ \\
\hline Lipa & -1.3 & 1.1 & 1.1 & 2.4 & 5.62E-04 \\
\hline$B c 12 a 1 b$ & 1.1 & -1.0 & 1.2 & 2.4 & 2.06E-02 \\
\hline $117 r$ & -1.0 & 1.0 & 1.5 & 2.4 & $3.71 E-02$ \\
\hline$F n 1$ & -1.0 & -1.2 & -1.4 & 2.3 & 4.24E-02 \\
\hline Mrcl & -1.0 & 1.1 & 1.1 & 2.3 & 1.14E-02 \\
\hline Ctsd & -1.1 & 1.2 & 1.4 & 2.3 & 4.87E-04 \\
\hline$H C$ & 1.1 & -1.1 & -1.3 & 2.1 & $1.94 E-02$ \\
\hline Ptgir & -1.0 & 1.1 & -1.1 & 2.1 & 1.91E-02 \\
\hline Lilra5 & 1.0 & -1.2 & 1.1 & 2.1 & $3.40 E-03$ \\
\hline Dhcr7 & -1.1 & -1.1 & 1.1 & 2.1 & $2.55 E-02$ \\
\hline Tnfrsf26 & -1.0 & 1.0 & 1.2 & 2.1 & 1.29E-02 \\
\hline Fnip2 & 1.1 & 1.4 & 1.2 & 2.1 & $1.33 E-02$ \\
\hline Acp5 & -1.0 & 1.0 & 1.7 & 2.1 & $9.46 E-03$ \\
\hline Myo5a & 1.1 & -1.2 & 1.0 & 2.0 & 2.85E-02 \\
\hline Syk & -1.0 & 1.1 & 1.2 & 2.0 & $1.68 E-02$ \\
\hline Fetub & -1.1 & 1.3 & 1.5 & 2.0 & $3.92 E-02$ \\
\hline
\end{tabular}

Differentially expressed (fold-change $>2$; FDR $<0.05$ ) genes between WT versus Scnn $1 b$-Tg from whole lung. Genes are listed if they were significant at one or more of the four developmental stages measured. Fold-change represents Scnn1b-Tg:WT. Up-regulated and down-regulated fold-changes are highlighted bold and italics, respectively. 
Table 5 Differentially regulated Gene Ontology groups from whole lung between WT and Scnn1b-Tg mice

\begin{tabular}{|c|c|c|c|}
\hline PND 0 & PND 3 & PND 10 & PND 42 \\
\hline \multicolumn{4}{|l|}{ UP-REGULATED } \\
\hline GO:0031424 & NONE* & GO:0006953 & GO:0006954 \\
\hline Keratinization & & Acute-phase response & Inflammatory response \\
\hline GO:0035195 & & GO:0002526 & GO:0050715 \\
\hline Gene silencing by miRNA & & Acute inflammatory response & $\begin{array}{l}\text { Positive regulation of cytokine } \\
\text { secretion }\end{array}$ \\
\hline GO:0090505 & & GO:0050707 & GO:0001816 \\
\hline Epiboly involved in wound healing & & Regulation of cytokine secretion & Cytokine production \\
\hline GO:0090504 & & GO:0003341 & GO:0050663 \\
\hline Epiboly & & Cilium movement & Cytokine secretion \\
\hline GO:0035194 & & GO:0050715 & GO:0002444 \\
\hline Posttranscriptional gene silencing by RNA & & $\begin{array}{l}\text { Positive regulation of cytokine } \\
\text { secretion }\end{array}$ & $\begin{array}{l}\text { Myeloid leukocyte mediated } \\
\text { immunity }\end{array}$ \\
\hline GO:0044319 & & GO:0006954 & GO:0002274 \\
\hline Wound healing, spreading of cells & & Inflammatory response & Myeloid leukocyte activation \\
\hline GO:0035278 & & GO:0045087 & GO:0050707 \\
\hline $\begin{array}{c}\text { Negative regulation of translation involved in gene } \\
\text { silencing by miRNA }\end{array}$ & & Innate immune response & $\begin{array}{l}\text { Regulation of cytokine } \\
\text { secretion }\end{array}$ \\
\hline GO:0045974 & & GO:0032640 & GO:0043299 \\
\hline Regulation of translation, ncRNA-mediated & & Tumor necrosis factor production & Leukocyte degranulation \\
\hline GO:0035313 & & GO:0002886 & GO:0006955 \\
\hline Wound healing, spreading of epidermal cells & & $\begin{array}{l}\text { Regulation of myeloid leukocyte } \\
\text { mediated immunity }\end{array}$ & Immune response \\
\hline GO:0040033 & & GO:0044782 & GO:0050729 \\
\hline Negative regulation of translation, ncRNA-mediated & & Cilium organization & $\begin{array}{l}\text { Positive regulation of } \\
\text { inflammatory response }\end{array}$ \\
\hline \multicolumn{4}{|l|}{ DOWN-REGULATED } \\
\hline GO:0048002 & GO:0007059 & GO:0043931 & NONE* \\
\hline $\begin{array}{l}\text { Antigen processing and presentation of peptide } \\
\text { antigen }\end{array}$ & $\begin{array}{l}\text { Chromosome } \\
\text { segregation }\end{array}$ & $\begin{array}{l}\text { Ossification involved in bone } \\
\text { maturation }\end{array}$ & \\
\hline GO:0009410 & GO:0007067 & GO:0061298 & \\
\hline Response to xenobiotic stimulus & Mitosis & $\begin{array}{l}\text { Retina vasculature development in } \\
\text { camera-type eye }\end{array}$ & \\
\hline GO:0006805 & GO:0000280 & GO:0060039 & \\
\hline Xenobiotic metabolic process & Nuclear division & Pericardium development & \\
\hline GO:0002495 & GO:0048285 & GO:0070977 & \\
\hline $\begin{array}{c}\text { Antigen processing and presentation of peptide } \\
\text { antigen via MHC class II }\end{array}$ & Organelle fission & Bone maturation & \\
\hline GO:0071466 & GO:0051301 & GO:0002067 & \\
\hline Cellular response to xenobiotic stimulus & Cell division & $\begin{array}{l}\text { Glandular epithelial cell } \\
\text { differentiation }\end{array}$ & \\
\hline GO:0002367 & GO:0071103 & GO:0030198 & \\
\hline Cytokine production involved in immune response & $\begin{array}{l}\text { DNA conformation } \\
\text { change }\end{array}$ & Extracellular matrix organization & \\
\hline GO:0002374 & GO:0006260 & GO:0043062 & \\
\hline Cytokine secretion involved in immune response & DNA replication & Extracellular structure organization & \\
\hline \multirow[t]{2}{*}{ GO:0002478 } & GO:0006261 & GO:0097435 & \\
\hline & & Fibril organization & \\
\hline
\end{tabular}


Table 5 Differentially regulated Gene Ontology groups from whole lung between WT and Scnn1b-Tg mice (Continued)

\begin{tabular}{|c|c|c|}
\hline $\begin{array}{l}\text { Antigen processing and presentation of exogenous } \\
\text { peptide antigen }\end{array}$ & $\begin{array}{l}\text { DNA-dependent DNA } \\
\text { replication }\end{array}$ & \\
\hline GO:0034381 & GO:0051297 & GO:0007044 \\
\hline Plasma lipoprotein particle clearance & $\begin{array}{l}\text { Centrosome } \\
\text { organization }\end{array}$ & Cell-substrate junction assembly \\
\hline GO:0097006 & GO:0000278 & GO:0050919 \\
\hline Regulation of plasma lipoprotein particle levels & Mitotic cell cycle & Negative chemotaxis \\
\hline
\end{tabular}

Top ten differentially up- and down-regulated Gene Ontology groups from whole lung between WT and Scnn 16 -Tg mice at the four developmental stages. Groups are only listed if FDR $<0.1$.

NONE indicates that no groups reached the significance threshold $(F D R<0.1)$.

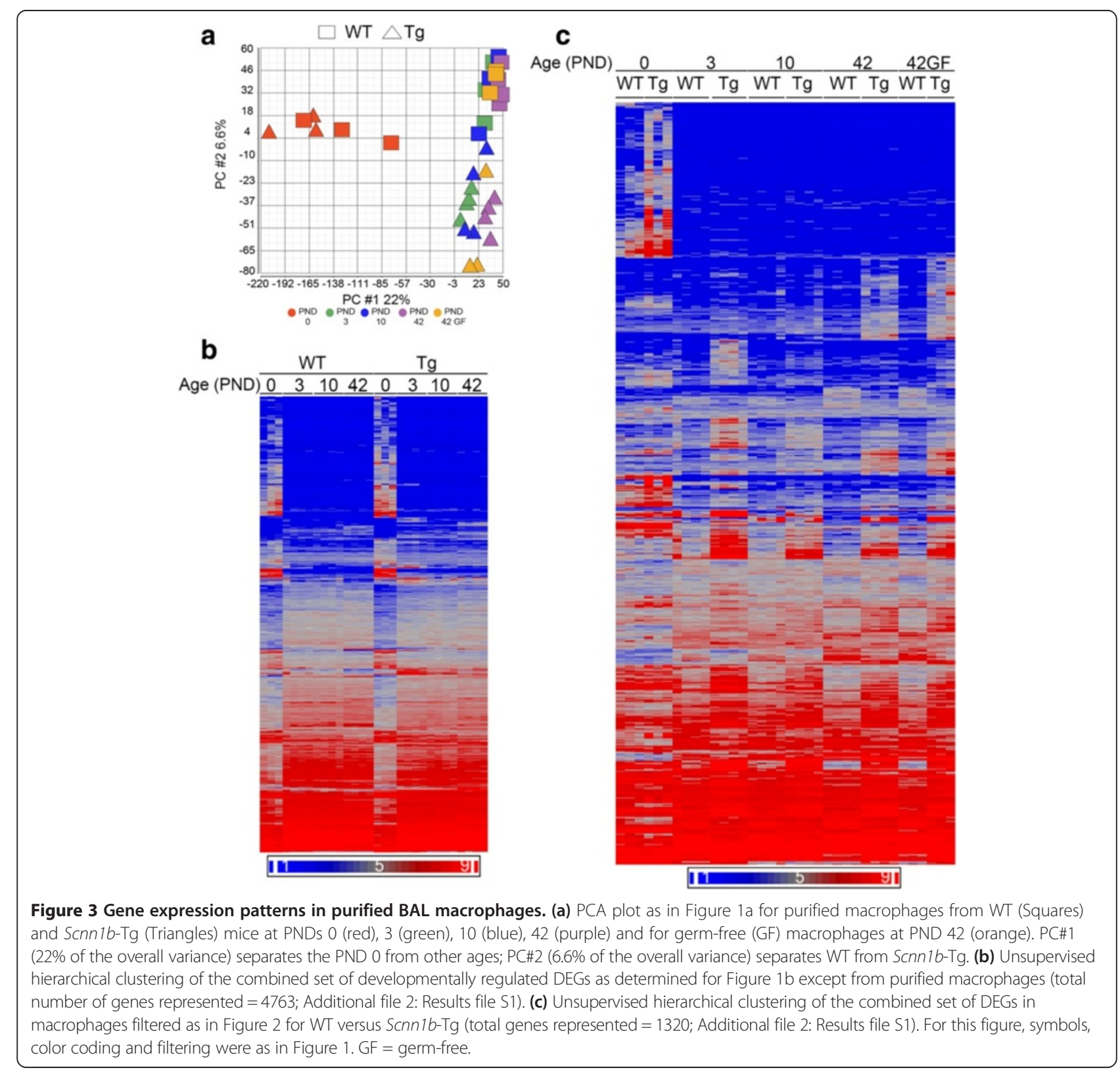


contribution of each cell type varying between WT and Scnn1b-Tg and among developmental time points. To minimize granulocytes proportions in the BAL, macrophages were purified by negative selection for Ly6G expression (a marker exclusively expressed on neutrophils and eosinophils), and pools with $95.86 \% \pm 0.25 \%$ (SEM) purity were obtained (Additional file 1: Figure S3 and Additional file 3: Table S2). Lack of Ly-6G expression in all macrophage preparations used in this study was confirmed by gene array data (data not shown).
PCA analysis of purified macrophage arrays showed both age and genotype as drivers of global gene expression variation (Figure 3a). PC1 separated macrophages at PND 0 from later time points. However, PC2 separated macrophages from Scnn1b-Tg and WT mice at PND 3, PND 10, and PND 42, indicating disease-specific activation of gene signatures. PND $0 \mathrm{WT}$ and $S c n n 1 b-\mathrm{Tg}$ macrophages separated primarily in PC5, with other PCs reflecting either age or other unexplained variation (Additional file 1: Figure S1b). Interestingly, macrophages

Table 6 Developmentally regulated genes in purified macrophages from WT mice

\begin{tabular}{|c|c|c|c|c|c|c|c|c|}
\hline \multirow{2}{*}{$\begin{array}{l}\text { Gene } \\
\text { Name }\end{array}$} & \multicolumn{2}{|c|}{ Fold-change: PND 3 vs 0} & \multirow{2}{*}{$\begin{array}{l}\text { Gene } \\
\text { Name }\end{array}$} & \multicolumn{2}{|c|}{ Fold-change: PND 10 vs 3} & \multirow{2}{*}{$\begin{array}{c}\text { Gene } \\
\text { Name }\end{array}$} & \multicolumn{2}{|c|}{ Fold-change: PND 42 vs 10} \\
\hline & WT & Scnn1b-Tg & & WT & Scnn1b-Tg & & WT & Scnn1b-Tg \\
\hline \multicolumn{9}{|l|}{ UP-REGULATED } \\
\hline Fabpl & 42.2 & 8.6 & Ear11 & 39.5 & 10.5 & Spag11b & 23.8 & 21.0 \\
\hline Coro6 & 24.3 & 3.0 & Fbp 1 & 18.0 & 3.8 & Cpne5 & 18.7 & 7.0 \\
\hline Trem/4 & 24.1 & 13.2 & $\mathrm{Cc} 124$ & 12.2 & 4.6 & S/c9a2 & 10.2 & 2.5 \\
\hline Rnase6 & 14.1 & 6.0 & Retnlg & 12.0 & -2.1 & $\operatorname{Lrg} 1$ & 7.4 & 3.1 \\
\hline F630028010Rik* & 13.5 & 12.3 & Retnla & 9.8 & 1.0 & Pnpla5 & 6.5 & 2.0 \\
\hline Gm4070 & 10.8 & 4.7 & $\mathrm{Ccl} 17$ & 9.4 & 5.0 & Ucp3 & 6.4 & 5.8 \\
\hline AW112010 & 10.6 & 13.9 & Alox15 & 4.3 & 1.9 & Epcam & 6.2 & 1.5 \\
\hline Mcoln3 & 9.4 & 18.6 & $\operatorname{Arg} 1$ & 4.1 & -1.8 & Gca & 5.4 & 3.1 \\
\hline Gbgt1 & 8.6 & 8.3 & $\operatorname{Prg} 2$ & 3.6 & 1.4 & 5730507C01Rik & 5.4 & 3.5 \\
\hline $\operatorname{lrg} 1$ & 8.5 & 118.2 & Ch25h & 3.3 & 3.9 & D630039A03Rik & 5.3 & 6.2 \\
\hline Alox5 & 8.5 & 4.1 & $\mathrm{H} 2-\mathrm{Ab} 1$ & 3.1 & 2.2 & Gm26154* & 4.8 & 1.5 \\
\hline 2010016118Rik & 8.4 & 6.5 & $\mathrm{H} 2-\mathrm{Aa}$ & 3.0 & 2.0 & $C d 74$ & 4.8 & 5.9 \\
\hline Rab44 & 8.3 & 3.1 & 1113 & 3.0 & 1.4 & Gal & 4.8 & 2.1 \\
\hline$C f b$ & 8.3 & 11.4 & Mmp12 & 3.0 & 1.9 & $H 2-A b 1$ & 4.7 & 5.8 \\
\hline Fpr1 & 8.0 & 15.5 & Serpine1 & 2.9 & 1.6 & Tnfsfi3b & 4.6 & -1.1 \\
\hline \multicolumn{9}{|c|}{ DOWN-REGULATED } \\
\hline Agr2 & -223.2 & -171.4 & $H p$ & -10.4 & -5.4 & Ear11 & -44.3 & 14.0 \\
\hline Chad & -105.2 & -163.4 & Scgblar & -9.7 & -4.1 & Fbp 1 & -19.1 & 15.8 \\
\hline Muc5b & -83.9 & -113.5 & $\mathrm{Saa} 3$ & -8.6 & -51.9 & S100a9 & -16.8 & -3.0 \\
\hline Meg3* & -65.4 & -84.1 & $\operatorname{lrg} 1$ & -7.8 & -6.3 & $\operatorname{Arg} 1$ & -14.3 & 2.4 \\
\hline Lypd2 & -64.7 & -83.5 & Scgb3a1 & -6.7 & -8.2 & Retnlg & -14.0 & 1.6 \\
\hline Muc16 & -63.4 & -83.4 & $\operatorname{Reg} 3 g$ & -6.3 & -10.5 & Retnla & -13.7 & 10.6 \\
\hline Gp2 & -60.9 & -92.3 & Xist* & -6.2 & -9.8 & $\mathrm{CCl} 24$ & -12.6 & 3.8 \\
\hline Krt7 & -60.1 & -51.7 & Clecte & -5.4 & -1.7 & Mmp12 & -10.1 & -1.2 \\
\hline Atp1b1 & -58.6 & -56.7 & SIc4al & -5.3 & -4.6 & AA467197 & -7.6 & 1.0 \\
\hline $\lg f 2$ & -57.4 & -78.0 & Rsad2 & -5.1 & -3.5 & $A B 124611$ & -6.3 & -2.9 \\
\hline$H 19^{*}$ & -57.3 & -137.5 & Mmp14 & -4.8 & -1.8 & $L d h b$ & -6.0 & -5.1 \\
\hline Ms/n & -54.2 & -7.1 & $B C 100530$ & -4.7 & -3.1 & Tarm1 & -5.9 & -1.5 \\
\hline Clic3 & -53.7 & -5.9 & Alas2 & -4.1 & -3.1 & Itgam & -5.8 & -2.4 \\
\hline AU021092 & -52.9 & -5.7 & Gm5416 & -4.0 & -36.8 & Ebi3 & -5.8 & -4.6 \\
\hline BC048546 & -52.9 & -5.7 & Gypa & -4.0 & -3.2 & Alox15 & -5.6 & 3.5 \\
\hline
\end{tabular}


purified from germ-free (GF) mice clustered close to their age-matched SPF counterparts.

As with the whole lung, the population of macrophages purified from the BAL exhibited robust developmental patterns, evident at all time points (Tables 6, 7 and 8). Evaluation of the top-signaling genes generated a complex picture with a number of obvious differences between WT and Scnn $1 b$-Tg mice, especially noticeable at the PND 42 versus PND 10 interval, where genes downregulated in WT mice were up-regulated in Scnn1b-Tg mice (Table 6) and vice versa (Table 7). The especially robust differential gene expression between the PND 0 and PND 3 time point (Figure 3b; Additional file 2: Results file S1) is consistent with previous studies identifying this interval as a key interval for alveolar macrophage differentiation [39]. Robust up-regulation of Siglec5 and Itgax (also known as SiglecF and Cd11c; fold-change 7.7 and 5.0, and FDR 1.0E-10 and 2.7E-9, respectively) between PND 0 and PND 3, which then stabilized between all other intervals (fold changes $<1.5$; FDR $>0.3$; not shown), confirmed the previous observations that these cell surface markers appear suddenly and that they

Table 7 Developmentally regulated genes in purified macrophages from Scnn 1b-Tg mice

\begin{tabular}{|c|c|c|c|c|c|c|c|c|}
\hline \multirow{2}{*}{$\begin{array}{l}\text { Gene } \\
\text { Name }\end{array}$} & \multicolumn{2}{|c|}{ Fold change: PND 3 vs 0} & \multirow{2}{*}{$\begin{array}{l}\text { Gene } \\
\text { Name }\end{array}$} & \multicolumn{2}{|c|}{ Fold change: PND 10 vs 3} & \multirow{2}{*}{$\begin{array}{l}\text { Gene } \\
\text { Name }\end{array}$} & \multicolumn{2}{|c|}{ Fold change: PND 42 vs 10} \\
\hline & Scnn 1b-Tg & WT & & Scnn1b-Tg & WT & & Scnn1b-Tg & WT \\
\hline \multicolumn{9}{|c|}{ UP-REGULATED } \\
\hline $\operatorname{lrg} 1$ & 118.2 & 8.5 & Earn1 & 10.5 & 39.5 & Rbp4 & 69.2 & -1.8 \\
\hline Saa3 & 55.5 & 5.5 & Fabpl & 6.7 & 2.4 & Spag11b & 21.0 & 23.8 \\
\hline Clec4e & 52.9 & 8.0 & Ccl17 & 5.0 & 9.4 & Fbp 1 & 15.8 & -19.1 \\
\hline Gpr84 & 40.7 & 3.5 & $\mathrm{Cc} / 24$ & 4.6 & 12.2 & Earn1 & 14.0 & -44.3 \\
\hline Inhba & 39.3 & 1.8 & Coro6 & 4.3 & 1.8 & Awat1 & 13.4 & -3.4 \\
\hline Gm5416 & 32.3 & -1.6 & Ch25h & 3.9 & 3.3 & Bex1 & 12.8 & -1.5 \\
\hline $1 / 7 f 9$ & 32.2 & 3.6 & Sorbs3 & 3.8 & 2.4 & Retnla & 10.6 & -13.7 \\
\hline $\mathrm{CxCl} 3$ & 26.2 & 1.9 & Fbp 1 & 3.8 & 18.0 & Sox7 & 10.0 & -1.1 \\
\hline S/c11ar & 23.2 & 2.2 & Sftpc & 3.2 & 1.0 & Lhx2 & 9.5 & -1.2 \\
\hline Pla2g7 & 23.1 & 4.3 & Ear5 & 3.2 & 2.4 & Scgbial & 8.5 & 3.2 \\
\hline $\mathrm{Ccrl} 2$ & 21.5 & 4.6 & Mapib & 3.1 & -1.1 & Slcla2 & 7.8 & 1.0 \\
\hline Mcoln3 & 18.6 & 9.4 & Ffar4 & 3.0 & 1.8 & Arnt2 & 7.2 & 1.0 \\
\hline Aoah & 18.3 & 3.9 & Pdk4 & 2.9 & 1.6 & Cpnes & 7.0 & 18.7 \\
\hline Slc7a11 & 17.6 & 5.3 & $\mathrm{Htr} 2 \mathrm{C}$ & 2.9 & 2.2 & Scdl & 6.9 & 1.6 \\
\hline $\mathrm{CxCl1}$ & 17.0 & 1.1 & Mamdc2 & 2.9 & 1.4 & Ear5 & 6.8 & -1.0 \\
\hline \multicolumn{9}{|c|}{ DOWN-REGULATED } \\
\hline Agr2 & -171.4 & -223.2 & Stfa3 & -60.6 & -2.8 & BC100530 & -9.0 & -3.9 \\
\hline Chad & -163.4 & -105.2 & $\mathrm{Saa3}$ & -51.9 & -8.6 & Mmp14 & -7.9 & -1.5 \\
\hline H19* & -137.5 & -57.3 & $\operatorname{Len} 2$ & -48.9 & -3.8 & $\mathrm{~N}+5 e$ & -7.9 & -1.3 \\
\hline$T c f 21$ & -129.7 & -36.3 & Gm5416 & -36.8 & -4.0 & $H p$ & -7.6 & -1.3 \\
\hline Fmo2 & -119.6 & -36.6 & BC100530 & -27.9 & -4.7 & Stfa2/1 & -6.5 & -2.9 \\
\hline Muc5b & -113.5 & -83.9 & Stfa2 & -24.4 & -2.6 & $\operatorname{lrg} 1$ & -6.2 & 1.0 \\
\hline AU021092 & -92.4 & -52.9 & Chi3/1 & -20.0 & -1.7 & Spink2 & -5.9 & -5.0 \\
\hline Gp2 & -92.3 & -60.9 & Stfa2/1 & -19.0 & -2.8 & Clec4e & -5.8 & 2.0 \\
\hline Meg3* $^{*}$ & -84.1 & -65.4 & S100a9 & -18.9 & -1.8 & $\mathrm{CxCl} 2$ & -5.8 & -1.9 \\
\hline Lypd2 & -83.5 & -64.7 & Olfm4 & -15.5 & -1.5 & Apoc2 & -5.3 & -2.9 \\
\hline Muc16 & -83.4 & -63.4 & Asprv1 & -13.8 & -1.8 & Apoe & -5.2 & -3.8 \\
\hline $\operatorname{lgf2}$ & -78.0 & -57.4 & Prok2 & -12.3 & -1.1 & $L d h b$ & -5.1 & -6.0 \\
\hline Actal & -76.7 & -2.0 & Thbs 1 & -12.2 & -1.8 & Hilpda & -5.0 & -1.2 \\
\hline Fhl1 & -72.2 & -21.6 & $111 r 2$ & -12.0 & -1.4 & Lpcat2 & -4.9 & -1.6 \\
\hline BC048546 & -71.2 & -52.9 & Ifitml & -11.2 & -1.7 & Sftpc & -4.8 & -1.6 \\
\hline
\end{tabular}


Table 8 Developmentally regulated Gene Ontology groups in purified macrophages from WT and Scnn 1b-Tg mice

\begin{tabular}{|c|c|c|c|c|c|}
\hline \multicolumn{2}{|c|}{ PND 3 vs PND 0} & \multicolumn{2}{|c|}{ PND 10 vs PND 3} & \multicolumn{2}{|c|}{ PND 42 vs PND 10} \\
\hline WT & Scnn $1 b-\mathrm{Tg}$ & WT & Scnn $1 b-\mathrm{Tg}$ & WT & Scnn $1 b-\mathrm{Tg}$ \\
\hline \multicolumn{6}{|l|}{ UP-REGULATED } \\
\hline $\begin{array}{c}\text { GO:0007059 } \\
\text { Chromosome } \\
\text { segregation }\end{array}$ & $\begin{array}{l}\text { GO:0019882 Antigen } \\
\text { processing and presentation }\end{array}$ & NONE* & NONE* & $\begin{array}{l}\text { GO:0007157 Heterophilic } \\
\text { cell-cell adhesion }\end{array}$ & $\begin{array}{c}\text { GO:0032944 Regulation } \\
\text { of mononuclear cell } \\
\text { proliferation }\end{array}$ \\
\hline $\begin{array}{l}\text { GO:0000070 } \\
\text { Mitotic sister } \\
\text { chromatid } \\
\text { segregation }\end{array}$ & $\begin{array}{c}\text { GO:0007059 Chromosome } \\
\text { segregation }\end{array}$ & & & NONE* & $\begin{array}{c}\text { GO:0070663 Regulation } \\
\text { of leukocyte } \\
\text { proliferation }\end{array}$ \\
\hline $\begin{array}{l}\text { GO:0000819 Sister } \\
\text { chromatid } \\
\text { segregation }\end{array}$ & $\begin{array}{l}\mathrm{GO}: 0048002 \text { Antigen } \\
\text { processing and presentation of } \\
\text { peptide antigen }\end{array}$ & & & & $\begin{array}{c}\text { GO:0050670 Regulation } \\
\text { of lymphocyte } \\
\text { proliferation }\end{array}$ \\
\hline $\begin{array}{l}\text { GO:0006310 DNA } \\
\text { recombination }\end{array}$ & $\begin{array}{l}\text { GO:0071346 Cellular response } \\
\text { to interferon-gamma }\end{array}$ & & & & $\begin{array}{l}\text { GO:0045058 T cell } \\
\text { selection }\end{array}$ \\
\hline $\begin{array}{l}\text { GO:0006302 } \\
\text { Double-strand } \\
\text { break repair }\end{array}$ & $\begin{array}{l}\text { GO:0032615 Interleukin-12 } \\
\text { production }\end{array}$ & & & & $\begin{array}{l}\text { GO:0050870 Positive } \\
\text { regulation of T cell } \\
\text { activation }\end{array}$ \\
\hline $\begin{array}{l}\text { GO:0007067 } \\
\text { Mitosis }\end{array}$ & $\begin{array}{l}\text { GO:0032655 Regulation of } \\
\text { interleukin-12 production }\end{array}$ & & & & $\begin{array}{l}\text { GO:0042129 Regulation } \\
\text { of T cell proliferation }\end{array}$ \\
\hline $\begin{array}{l}\text { GO:0006281 DNA } \\
\text { repair }\end{array}$ & $\begin{array}{c}\text { GO:0045087 Innate immune } \\
\text { response }\end{array}$ & & & & $\begin{array}{l}\text { GO:0006720 Isoprenoid } \\
\text { metabolic process }\end{array}$ \\
\hline $\begin{array}{l}\text { GO:0048285 } \\
\text { Organelle fission }\end{array}$ & $\begin{array}{l}\mathrm{GO}: 0002474 \text { Antigen } \\
\text { processing and presentation of } \\
\text { peptide antigen via MHC class }\end{array}$ & & & & $\begin{array}{l}\text { GO:0051251 Positive } \\
\text { regulation of } \\
\text { lymphocyte activation }\end{array}$ \\
\hline $\begin{array}{l}\text { GO:0000280 } \\
\text { Nuclear division }\end{array}$ & $\begin{array}{c}\text { GO:0032606 Type I interferon } \\
\text { production }\end{array}$ & & & & $\begin{array}{l}\text { GO:0048002 Antigen } \\
\text { processing and } \\
\text { presentation of peptide } \\
\text { antigen }\end{array}$ \\
\hline $\begin{array}{l}\text { GO:0000725 } \\
\text { Recombinational } \\
\text { repair }\end{array}$ & $\begin{array}{l}\text { GO:0032479 Regulation of type } \\
\text { I interferon production }\end{array}$ & & & & $\begin{array}{l}\text { GO:0070661 Leukocyte } \\
\text { proliferation }\end{array}$ \\
\hline \multicolumn{6}{|l|}{ DOWN-REGULATED } \\
\hline $\begin{array}{l}\text { GO:0060541 } \\
\text { Respiratory } \\
\text { system } \\
\text { development }\end{array}$ & $\begin{array}{c}\text { GO:0060485 Mesenchyme } \\
\text { development }\end{array}$ & $\begin{array}{l}\text { GO:0035456 } \\
\text { Response to } \\
\text { interferon-beta }\end{array}$ & $\begin{array}{c}\text { GO:0030595 Leukocyte } \\
\text { chemotaxis }\end{array}$ & $\begin{array}{l}\text { GO:0007059 } \\
\text { Chromosome } \\
\text { segregation }\end{array}$ & GO:0007067 Mitosis \\
\hline $\begin{array}{l}\text { GO:0030324 } \\
\text { Lung } \\
\text { development }\end{array}$ & $\begin{array}{c}\text { GO:0030324 Lung } \\
\text { development }\end{array}$ & $\begin{array}{l}\text { GO:0035458 } \\
\text { Cellular response } \\
\text { to interferon-beta }\end{array}$ & $\begin{array}{c}\text { GO:0050900 Leukocyte } \\
\text { migration }\end{array}$ & GO:0007067 Mitosis & $\begin{array}{l}\text { GO:0000280 Nuclear } \\
\text { division }\end{array}$ \\
\hline $\begin{array}{l}\text { GO:0030323 } \\
\text { Respiratory tube } \\
\text { development }\end{array}$ & $\begin{array}{c}\text { G00030323 Respiratory tube } \\
\text { development }\end{array}$ & $\begin{array}{l}\text { GO:0045087 } \\
\text { Innate immune } \\
\text { response }\end{array}$ & $\begin{array}{l}\text { GO:0045087 Innate } \\
\text { immune response }\end{array}$ & $\begin{array}{c}\text { GO:0000280 Nuclear } \\
\text { division }\end{array}$ & $\begin{array}{l}\text { GO:0007059 } \\
\text { Chromosome } \\
\text { segregation }\end{array}$ \\
\hline $\begin{array}{l}\text { GO:0060485 } \\
\text { Mesenchyme } \\
\text { development }\end{array}$ & $\begin{array}{l}\text { GO:0060541 Respiratory } \\
\text { system development }\end{array}$ & $\begin{array}{l}\text { GO:0045851 pH } \\
\text { reduction }\end{array}$ & $\begin{array}{c}\text { GO:0006954 } \\
\text { Inflammatory response }\end{array}$ & $\begin{array}{l}\text { GO:0048285 Organelle } \\
\text { fission }\end{array}$ & $\begin{array}{l}\text { GO:0048285 Organelle } \\
\text { fission }\end{array}$ \\
\hline $\begin{array}{l}\text { GO:0002009 } \\
\text { Morphogenesis of } \\
\text { an epithelium }\end{array}$ & $\begin{array}{c}\text { GO:0001657 Ureteric bud } \\
\text { development }\end{array}$ & $\begin{array}{l}\text { GO:0051607 } \\
\text { Defense } \\
\text { response to virus }\end{array}$ & $\begin{array}{l}\text { GO:0006955 Immune } \\
\text { response }\end{array}$ & $\begin{array}{l}\text { GO:0000070 Mitotic } \\
\text { sister chromatid } \\
\text { segregation }\end{array}$ & $\begin{array}{l}\text { GO:0000819 Sister } \\
\text { chromatid segregation }\end{array}$ \\
\hline $\begin{array}{c}\text { GO:0048762 } \\
\text { Mesenchymal cell } \\
\text { differentiation }\end{array}$ & $\begin{array}{c}\text { GO:0055123 Digestive system } \\
\text { development }\end{array}$ & $\begin{array}{l}\text { GO:0051453 } \\
\text { Regulation of } \\
\text { intracellular pH }\end{array}$ & $\begin{array}{l}\text { GO:0060326 Cell } \\
\text { chemotaxis }\end{array}$ & $\begin{array}{l}\text { GO:0000819 Sister } \\
\text { chromatid segregation }\end{array}$ & $\begin{array}{c}\text { GO:0033700 } \\
\text { Phospholipid efflux }\end{array}$ \\
\hline $\begin{array}{l}\text { GO:0048729 } \\
\text { Tissue } \\
\text { morphogenesis }\end{array}$ & $\begin{array}{l}\text { GO:0048762 Mesenchymal } \\
\text { cell differentiation }\end{array}$ & $\begin{array}{l}\mathrm{GO}: 0051452 \\
\text { Intracellular pH } \\
\text { reduction }\end{array}$ & $\begin{array}{l}\text { GO:0048520 Positive } \\
\text { regulation of behavior }\end{array}$ & $\begin{array}{l}\text { GO:0000278 Mitotic cell } \\
\text { cycle }\end{array}$ & $\begin{array}{l}\text { GO:0000070 Mitotic } \\
\text { sister chromatid } \\
\text { segregation }\end{array}$ \\
\hline
\end{tabular}


Table 8 Developmentally regulated Gene Ontology groups in purified macrophages from WT and Scnn $1 b$-Tg mice (Continued)

\begin{tabular}{|c|c|c|c|c|c|}
\hline $\begin{array}{l}\text { GO:0003007 Heart } \\
\text { morphogenesis }\end{array}$ & $\begin{array}{l}\text { GO:0048562 Embryonic } \\
\text { organ morphogenesis }\end{array}$ & $\begin{array}{l}\text { GO:0048525 } \\
\text { Negative } \\
\text { regulation of viral } \\
\text { process }\end{array}$ & $\begin{array}{l}\text { GO:0032103 Positive } \\
\text { regulation of response } \\
\text { to external stimulus }\end{array}$ & $\begin{array}{c}\text { GO:0000725 } \\
\text { Recombinational repair }\end{array}$ & $\begin{array}{l}\text { GO:0007052 Mitotic } \\
\text { spindle organization }\end{array}$ \\
\hline $\begin{array}{c}\text { GO:0048562 } \\
\text { Embryonic organ } \\
\text { morphogenesis }\end{array}$ & $\begin{array}{c}\text { GO:0048565 Digestive tract } \\
\text { development }\end{array}$ & $\begin{array}{l}\text { GO:0030641 } \\
\text { Regulation of } \\
\text { cellular pH }\end{array}$ & $\begin{array}{l}\text { GO:0002690 Positive } \\
\text { regulation of } \\
\text { leukocyte chemotaxis }\end{array}$ & $\begin{array}{l}\text { GO:0007052 Mitotic } \\
\text { spindle organization }\end{array}$ & $\begin{array}{l}\text { GO:0070301 Cellular } \\
\text { response to hydrogen } \\
\text { peroxide }\end{array}$ \\
\hline $\begin{array}{l}\text { GO:0010632 } \\
\text { Regulation of } \\
\text { epithelial cell } \\
\text { migration }\end{array}$ & $\begin{array}{l}\text { GO:2000736 Regulation of } \\
\text { stem cell differentiation }\end{array}$ & $\begin{array}{l}\text { GO:0002224 Toll- } \\
\text { like receptor } \\
\text { signaling } \\
\text { pathway }\end{array}$ & $\begin{array}{l}\text { GO:0002687 Positive } \\
\text { regulation of } \\
\text { leukocyte migration }\end{array}$ & $\begin{array}{c}\text { GO:0000724 Double- } \\
\text { strand break repair via } \\
\text { homologous } \\
\text { recombination }\end{array}$ & $\begin{array}{c}\text { GO:0090068 Positive } \\
\text { regulation of cell cycle } \\
\text { process }\end{array}$ \\
\hline
\end{tabular}

Top ten developmentally up- and down-regulated Gene Ontology groups for purified macrophages in WT and Scnn $1 b$-Tg mice between the specified developmental intervals. Gene Ontology groups in common between the WT and Scnn $1 b$-Tg line are highlighted by bolded and italicized text. Groups are only listed if FDR $<0.1$.

${ }^{*}$ NONE indicates that no groups met the significance threshold (FDR<0.1).

define the resident alveolar macrophage population immediately after birth in mice [39]. This dataset may be especially useful to identify transcriptional changes that accompany Siglec5 and Itgax up-regulation during this critical time.

GSEA pathways analysis was more informative than gene-level data to establish the overall trends (Table 8 Additional file 1 Figure S4). In the PND 0-3 interval, WT macrophages exhibited up-regulation of GO pathways involved in cell growth and differentiation, and, interestingly, up-regulation of pathways in WT mice at the later two intervals was minimal. Down-regulated signals during the PND 0-3 interval suggest that these early post-natal macrophages have the ability to respond to signals that are directing normal lung development and differentiation. We cannot rule out the possibility that the macrophage preparations contain a small percentage of epithelial cells, which would confound interpretation. However, epithelial cell contamination was not obvious histologically (data not shown). The strength of downregulated signals in macrophages for $\mathrm{GO}$ lung and respiratory development pathways (Table 8 ) during this interval suggest that lung epithelium and macrophages use similar signals to coordinate differentiation between the two tissues. Down-regulation of the cell proliferation pathways occurring in the WT and Scnn $1 b$-Tg mice at the PND 10-42 period are consistent with the establishment of long-lived, slow proliferating pulmonary macrophage populations during steady state $[39,40]$. Significant down-regulation of GO innate immune response pathways in both lines during the PND 3-10 interval points toward the steady-state, mature pulmonary macrophage as relatively quiescent and tolerant toward low danger stimuli. Finally, unlike WT macrophages, Scnn1b-Tg macrophages exhibited up-regulation of pathways involved in innate immune responses as expected from their morphologically activated state, with the GSEA signatures being especially robust between the PND 10 and PND 42 (Table 8). Further exploration by directly comparing gene expression between WT and Scnn1b-Tg macrophages provided additional insights.

As expected from the PCA, DEGs were identified between WT and Scnn1b-Tg macrophages at each time point evaluated, with 432, 394, 166, and 437 DEGs at PND 0, 3, 10, and 42, respectively, using the established significance threshold $(\mathrm{FC} \geq 2 ; \mathrm{FDR} \leq 0.05)$ (Figure 3c; Additional file 2: Results file S1). As expected from the previous discussion, the top-signaling genes vary across time and represent a variety of biological processes (Table 9). The most significant GO pathways upregulated by disease at PND 0 are related to muscle cell gene expression, which is difficult to reconcile with the known literature on pulmonary macrophages. However, by PND 3 and onward, significant up-regulation of a variety of inflammatory signatures was observed in the Scnn $1 b$-Tg mice compared to WT mice (Table 10). The down-regulation of GO pathways related to mitosis in Scnn $1 b$-Tg mice at the earlier time points (PND 3 and PND 10) indicate that Scnn $1 b-\mathrm{Tg}$ pulmonary macrophages are less prolific than their WT counterparts at these early post-natal ages, a shift that is likely a response to the altered cytokine milieu that develops in the $S c n n 1 b-\mathrm{Tg}$ mice as a response to the signals that are arising from the bacterial infections and/or necrotic club cells at these time points.

\section{Custom-annotated pathways allow assessment of disease-specific features}

The previously described GSEA analysis, based on publically available GO pathway annotations, provided evidence for activation of relevant biological pathways in both lung and macrophages during the development of disease. However, due to incomplete annotation, GO pathways are not expected to capture all processes specifically associated with lung biology and pulmonary diseases. 
Table 9 Differentially regulated genes between purified macrophages from Scnn $1 b$-Tg and WT mice

\begin{tabular}{|c|c|c|c|c|c|c|c|c|c|c|c|}
\hline \multicolumn{3}{|c|}{ PND 0} & \multicolumn{3}{|c|}{ PND 3} & \multicolumn{3}{|c|}{ PND 10} & \multicolumn{3}{|c|}{ PND 42} \\
\hline $\begin{array}{l}\text { Gene } \\
\text { Name }\end{array}$ & $\begin{array}{c}\text { Fold- } \\
\text { Change }\end{array}$ & $\begin{array}{l}\text { FDR p- } \\
\text { value }\end{array}$ & $\begin{array}{l}\text { Gene } \\
\text { Name }\end{array}$ & $\begin{array}{c}\text { Fold- } \\
\text { Change }\end{array}$ & $\begin{array}{l}\text { FDR p- } \\
\text { value }\end{array}$ & $\begin{array}{l}\text { Gene } \\
\text { Name }\end{array}$ & $\begin{array}{c}\text { Fold- } \\
\text { Change }\end{array}$ & $\begin{array}{l}\text { FDR } p- \\
\text { value }\end{array}$ & $\begin{array}{l}\text { Gene } \\
\text { Name }\end{array}$ & $\begin{array}{c}\text { Fold- } \\
\text { Change }\end{array}$ & $\begin{array}{l}\text { FDR } p- \\
\text { value }\end{array}$ \\
\hline \multicolumn{12}{|l|}{ UP-REGULATED } \\
\hline Actal & 43.4 & $9.12 E-16$ & $\operatorname{Len} 2$ & 42.6 & $4.11 E-05$ & Inhba & 25.8 & $1.04 E-05$ & Ear11 & 137.8 & 4.70E-06 \\
\hline Tnnc2 & 37.9 & $4.27 E-15$ & Stfa3 & 35.2 & $1.70 E-05$ & Mmp14 & 22.3 & $1.14 E-06$ & Fst/1 & 85.4 & $6.63 E-12$ \\
\hline Csn1s2a & 32.6 & $2.11 E-06$ & Gm5416 & 32.0 & 4.46E-05 & $\operatorname{lrg} 1$ & 17.1 & 9.85E-05 & Rbp4 & 70.5 & 3.57E-09 \\
\hline $\mathrm{Tg}$ & 25.9 & $3.53 E-03$ & Thbs 1 & 27.3 & 6.67E-06 & Npy & 15.3 & 4.18E-05 & Fbp 1 & 67.1 & 2.23E-05 \\
\hline $\operatorname{Csn} 2$ & 23.4 & $5.58 E-05$ & Stfa2 & 26.4 & $9.55 E-05$ & $\mathrm{H} 2-\mathrm{M} 2$ & 14.0 & $1.58 E-09$ & Mfge8 & 52.0 & $1.38 E-11$ \\
\hline Mylpf & 22.7 & 1.19E-07 & Chi3/1 & 20.6 & 8.07E-06 & Slc11ar & 12.8 & 5.51E-06 & Awat1 & 51.9 & $3.74 E-08$ \\
\hline Scnn $1 b$ & 21.5 & $2.01 E-03$ & Saa3 & 20.2 & $2.00 E-04$ & Clec4e & 12.3 & 5.88E-06 & $\operatorname{Arg} 1$ & 42.7 & 1.17E-05 \\
\hline Wap & 19.5 & 7.79E-04 & Inhba & 20.1 & $1.74 E-05$ & $\mathrm{CxCl} 2$ & 11.9 & 2.64E-06 & Inhba & 36.8 & 5.26E-07 \\
\hline SIc4al & 17.8 & $8.38 E-03$ & Cxcl1 & 15.8 & $2.63 E-06$ & Pmp22 & 11.0 & 1.20E-03 & Mmp12 & 33.9 & 7.64E-09 \\
\hline Glycam 1 & 17.7 & $3.44 E-04$ & Stfa2/1 & 15.8 & $2.75 E-03$ & Ass1 & 10.9 & 2.25E-05 & Retnla & 33.8 & $3.12 E-04$ \\
\hline Car3 & 16.1 & $1.90 E-03$ & Prok2 & 14.3 & $4.83 E-11$ & $H p$ & 10.3 & 7.72E-06 & Ppap2b & 27.8 & $3.32 E-12$ \\
\hline Rsad2 & 16.0 & $2.29 E-03$ & Plbd1 & 14.0 & $4.65 E-05$ & Mfge8 & 10.0 & 1.22E-06 & $\mathrm{H} 2-\mathrm{M} 2$ & 25.0 & $6.63 E-12$ \\
\hline Csn1s1 & 15.9 & $1.70 E-03$ & $\operatorname{lrg} 1$ & 13.9 & $1.09 E-04$ & $\mathrm{CxCl} 3$ & 9.7 & 2.62E-04 & $\mathrm{Cc} / 24$ & 24.2 & 1.07E-03 \\
\hline Tnnt3 & 15.2 & $1.58 E-08$ & Gm10872* & 13.9 & 7.19E-04 & Cxcl16 & 9.2 & 2.64E-06 & Bex1 & 18.9 & 2.04E-08 \\
\hline Gypa & 14.0 & $9.23 E-03$ & $\mathrm{CxCl} 3$ & 13.6 & $2.25 E-05$ & Pla2g7 & 8.4 & $3.15 E-04$ & AA467197 & 17.4 & 2.17E-07 \\
\hline \multicolumn{12}{|c|}{ DOWN-REGULATED } \\
\hline Gm10473 & -3.8 & $5.41 E-03$ & Coro6 & -6.1 & 4.47E-04 & Cidec & -2.7 & 1.07E-02 & Epcam & -5.2 & 4.79E-06 \\
\hline Gm24049* & -3.6 & $2.14 E-02$ & Hpgd & -5.1 & 4.44E-04 & Rab44 & -2.7 & 4.02E-04 & Gal & -5.1 & $6.71 E-04$ \\
\hline 6720489N17Rik & -3.3 & $2.23 E-02$ & Fabpl & -5.1 & $3.16 E-04$ & GOs2 & -2.6 & 1.33E-02 & Tnfsfi3b & -4.8 & $6.04 E-11$ \\
\hline Lilra5 & -2.9 & $5.01 E-04$ & Flt & -3.6 & 8.97E-06 & Fam212a & -2.6 & 4.99E-03 & Dnahc11 & -4.5 & $2.76 E-08$ \\
\hline 1600002K03Rik & -2.9 & 3.39E-02 & Kazald 1 & -3.4 & $2.10 E-03$ & Gm5936 & -2.5 & 2.25E-02 & Kazald 1 & -4.0 & 3.85E-04 \\
\hline Snora74a* & -2.8 & 4.99E-02 & Gpr34 & -2.9 & $6.50 E-04$ & Prr5l & -2.5 & $3.11 E-02$ & $\mathrm{~N}+5 e$ & -4.0 & 5.80E-05 \\
\hline Snora $73 b^{*}$ & -2.8 & $1.02 E-02$ & Slc6a4 & -2.9 & 3.94E-04 & Tmem150b & -2.4 & 9.43E-03 & Cpne5 & -3.9 & 4.10E-04 \\
\hline Gdf15 & -2.7 & $3.36 E-03$ & Gm1966 & -2.9 & $4.65 E-05$ & Csf3r & -2.4 & 2.37E-02 & Slc9a2 & -3.8 & 1.03E-05 \\
\hline Vgf & -2.7 & 3.30E-02 & Fam212a & -2.8 & 7.44E-04 & $C d 2$ & -2.4 & 4.82E-03 & Fam212a & -3.7 & 2.91E-05 \\
\hline 2010005H15Rik & -2.7 & 3.73E-02 & $\mathrm{Cd} 2$ & -2.8 & 3.54E-04 & Klk8 & -2.4 & 1.20E-02 & Egfem 1 & -3.7 & 9.82E-05 \\
\hline Aqp11 & -2.7 & $9.12 E-03$ & KIk8 & -2.8 & 9.32E-04 & Kenh4 & -2.3 & 1.19E-02 & Gpr141 & -3.7 & $2.18 E-03$ \\
\hline P2ry13 & -2.6 & $7.04 E-03$ & Gm11545 & -2.8 & 1.37E-02 & $\sec 1412$ & -2.2 & 7.39E-03 & Itgad & -3.5 & 1.23E-05 \\
\hline F630111L10Rik* & -2.6 & $1.26 E-02$ & Rnase6 & -2.8 & 1.17E-02 & Gm12258 & -2.2 & $2.18 E-02$ & lagap2 & -3.4 & 5.72E-06 \\
\hline Ch25h & -2.6 & $2.26 E-02$ & Trp53i11 & -2.8 & $2.74 E-02$ & Gsg2 & -2.1 & 4.20E-03 & Pnpla5 & -3.3 & $6.36 E-06$ \\
\hline Krt6a & -2.6 & $3.37 E-04$ & Cidec & -2.7 & $6.13 E-03$ & Arhgef39 & -2.0 & 1.36E-02 & Grap2 & -3.3 & 7.52E-04 \\
\hline
\end{tabular}

Differentially expressed up- and down-regulated (fold-change $>2$; FDR <0.05) genes between Scnn1b-Tg and WT mice from purified macrophages at the four developmental times. Fold-changes are Scnn1b-Tg:WT.

We hypothesized that additional insights could be provided utilizing custom pathway annotations created to query known, disease-relevant processes. To query our gene expression data for transcriptional events associated with specific pathologic features of the Scnn $1 b$-Tg model, customized gene lists were generated that reflected genes hypothesized or known to be involved in the pathogenesis of muco-obstructive lung diseases (Additional file 4: Results file S2 and Additional file 5: Results file S3). Custom pathways were developed either from compilation of literature, e.g., M1 polarized versus M2 polarized pathways, or by selecting genes known to be regulated under specific experimental conditions (e.g., allergen exposure, hypoxia, endoplasmic reticulum stress, autophagy, apoptosis) or cell-specific markers (macrophage activation, ciliated cells, mucous cell, inflammatory cell subsets, secreted antimicrobials) (Figure 4a; Additional file 4: Results file S2). A further group of pathways representing a number of disease-relevant gene expression signatures from human studies as defined by Chowdhary et. al. [41] were 
Table 10 Differentially regulated Gene Ontology groups from purified macrophages between WT and Scnn 16 -Tg mice

\begin{tabular}{|c|c|c|c|c|}
\hline PND 0 & PND 3 & PND 10 & PND 42 & PND 42 Germ-free \\
\hline \multicolumn{5}{|l|}{ UP-REGULATED } \\
\hline GO:0006936 & GO:0030595 & GO:0072593 & GO:0009611 & GO:0006954 \\
\hline Muscle contraction & Leukocyte chemotaxis & $\begin{array}{l}\text { Reactive oxygen species } \\
\text { metabolic process }\end{array}$ & Response to wounding & Inflammatory response \\
\hline GO:0003012 & GO:0032103 & GO:0030595 & GO:0032103 & GO:0009611 \\
\hline Muscle system process & $\begin{array}{l}\text { Positive regulation of } \\
\text { response to external stimulus }\end{array}$ & Leukocyte chemotaxis & $\begin{array}{l}\text { Positive regulation of } \\
\text { response to external } \\
\text { stimulus }\end{array}$ & Response to wounding \\
\hline GO:0003007 & GO:0060326 & GO:0060326 & GO:0030595 & GO:0030595 \\
\hline Heart morphogenesis & Cell chemotaxis & Cell chemotaxis & Leukocyte chemotaxis & Leukocyte chemotaxis \\
\hline GO:005500 & GO:0050900 & GO:0060445 & GO:0006954 & GO:0032103 \\
\hline $\begin{array}{l}\text { Striated muscle cell } \\
\text { development }\end{array}$ & Leukocyte migration & $\begin{array}{l}\text { Branching involved in salivary } \\
\text { gland morphogenesis }\end{array}$ & Inflammatory response & $\begin{array}{l}\text { Positive regulation of } \\
\text { response to external } \\
\text { stimulus }\end{array}$ \\
\hline GO:0060537 & GO:0006935 & GO:2000379 & GO:0071621 & GO:0071345 \\
\hline $\begin{array}{l}\text { Muscle tissue } \\
\text { development }\end{array}$ & Chemotaxis & $\begin{array}{c}\text { Positive regulation of reactive } \\
\text { oxygen species metabolic } \\
\text { process }\end{array}$ & Granulocyte chemotaxis & $\begin{array}{l}\text { Cellular response to } \\
\text { cytokine stimulus }\end{array}$ \\
\hline GO:0055001 & GO:0071621 & GO:0032103 & GO:0002687 & GO:0034097 \\
\hline Muscle cell development & Granulocyte chemotaxis & $\begin{array}{l}\text { Positive regulation of response } \\
\text { to external stimulus }\end{array}$ & $\begin{array}{l}\text { Positive regulation of } \\
\text { leukocyte migration }\end{array}$ & $\begin{array}{l}\text { Response to cytokine } \\
\text { stimulus }\end{array}$ \\
\hline GO:0043062 & GO:0002687 & GO:2000147 & GO:0002685 & GO:0042330 \\
\hline $\begin{array}{l}\text { Extracellular structure } \\
\text { organization }\end{array}$ & $\begin{array}{l}\text { Positive regulation of } \\
\text { leukocyte migration }\end{array}$ & $\begin{array}{l}\text { Positive regulation of cell } \\
\text { motility }\end{array}$ & $\begin{array}{c}\text { Regulation of leukocyte } \\
\text { migration }\end{array}$ & Taxis \\
\hline GO:0051216 & GO:0042330 & GO:0050921 & GO:0002253 & GO:0050714 \\
\hline Cartilage development & Taxis & Positive regulation of chemotaxis & $\begin{array}{l}\text { Activation of immune } \\
\text { response }\end{array}$ & $\begin{array}{l}\text { Positive regulation of } \\
\text { protein secretion }\end{array}$ \\
\hline GO:0031032 & GO:0050795 & GO:2000377 & GO:0002757 & GO:0006935 \\
\hline $\begin{array}{l}\text { Actomyosin structure } \\
\text { organization }\end{array}$ & Regulation of behavior & $\begin{array}{l}\text { Regulation of reactive oxygen } \\
\text { species metabolic process }\end{array}$ & $\begin{array}{l}\text { Immune response- } \\
\text { activating signal } \\
\text { transduction }\end{array}$ & Chemotaxis \\
\hline GO:0030239 & GO:0048520 & GO:0002690 & GO:0042330 & GO:0002685 \\
\hline \multirow[t]{2}{*}{ Myofibril assembly } & $\begin{array}{l}\text { Positive regulation of } \\
\text { behavior }\end{array}$ & $\begin{array}{l}\text { Positive regulation of leukocyte } \\
\text { chemotaxis }\end{array}$ & Taxis & $\begin{array}{c}\text { Regulation of leukocyte } \\
\text { migration }\end{array}$ \\
\hline & \multicolumn{3}{|c|}{ DOWN-REGULATED } & \\
\hline GO:0007186 & GO:0006996 & GO:0007059 & NONE* & NONE $^{*}$ \\
\hline $\begin{array}{l}\text { G-protein coupled } \\
\text { receptor signaling } \\
\text { pathway }\end{array}$ & Organelle organization & Chromosome segregation & & \\
\hline GO:0034470 & GO:0007059 & GO:0000819 & & \\
\hline ncRNA processing & Chromosome segregation & Sister chromatid segregation & & \\
\hline GO:0006364 & GO:0000819 & GO:0000070 & & \\
\hline rRNA processing & Sister chromatid segregation & $\begin{array}{l}\text { Mitotic sister chromatid } \\
\text { segregation }\end{array}$ & & \\
\hline GO:0016072 & GO:0006261 & GO:0032465 & & \\
\hline rRNA metabolic process & $\begin{array}{l}\text { DNA-dependent DNA } \\
\text { replication }\end{array}$ & Regulation of cytokinesis & & \\
\hline GO:0034660 & GO:0006302 & GO:0006281 & & \\
\hline ncRNA metabolic process & Double-strand break repair & DNA repair & & \\
\hline GO:0042254 & GO:0000070 & GO:0032508 & & \\
\hline
\end{tabular}


Table 10 Differentially regulated Gene Ontology groups from purified macrophages between WT and Scnn1b-Tg mice (Continued)

\begin{tabular}{ccc}
\hline Ribosome biogenesis & $\begin{array}{c}\text { Mitotic sister chromatid } \\
\text { segregation } \\
\text { GO:0045076 }\end{array}$ & GO:0007051 \\
$\begin{array}{c}\text { Regulation of interleukin- } \\
2 \text { biosynthetic process } \\
\text { GO:0008033 }\end{array}$ & Spindle organization & GO:0051983 \\
tRNA processing & GO:0051225 & $\begin{array}{c}\text { Regulation of chromosome } \\
\text { segregation }\end{array}$ \\
NONE* & Spindle assembly & GO:0007051 \\
& GO:0008608 & Spindle organization \\
& Attachment of spindle & GO:0000280 \\
& microtubules to kinetochore & Nuclear division \\
& GO:0000724 & GO:0007067 \\
& $\begin{array}{c}\text { Double-strand break repair via } \\
\text { homologous recombination }\end{array}$ & Mitosis
\end{tabular}

Top ten differentially up- and down-regulated Gene Ontology groups from purified macrophages between WT and Scnn $1 b$-Tg mice at the four developmental stages. Groups are only listed if FDR $<0.1$.

${ }^{*}$ NONE indicates that no groups or no additional groups met the significance threshold (FDR $\left.<0.1\right)$.

also queried (Figure 4b; Additional file 4: Results file S2). Literature and database references, as well as details related to the selection of genes in these pathways, are provided (Additional file 5: Results file S3 and Additional file 5: Results file S3 references).

Using these custom annotations, significant GSEA disease-relevant signatures were identified that were tissue/cell specific and time-dependent (Figure 4). In macrophages, substantial evidence for polarization into both M1 and M2 phenotypes was detected. With respect to whole lung, a previously unappreciated up-regulation of ciliated cell- and dendritic cell-specific genes in Scnn1b-Tg was identified at PND 3-10 and PND 42, respectively. Mucous cell signatures were consistently found in whole lung at PND 42 that correlated with the expression of epithelial genes previously reported to be induced by SAM-pointed domain-containing Ets-like factor (Spdef), a transcriptional regulator of mucous cell differentiation in mouse and humans [43]. Gene signatures for mucus production were consistent with previous reports [12]. Interestingly, strong upregulation of Spdef-associated genes was also observed in macrophages at each time point. A mucous cell signature in PND 3 whole lungs, which correlated with up-regulation of genes normally suppressed by Spdef over-expression, was also detected, suggesting a timedependent activation of alternative pathways. The gene expression pattern of whole lung for secreted antimicrobials correlated with the location and timing of spontaneous infection in Scnn1b-Tg mice. Signatures for hypoxia and protease/anti-protease activation were more variable across tissues and time points and more difficult to interpret.

Importantly for the use of this model in the context of human disease, strong up-regulation of human lung disease-specific signatures, including those for chronic obstructive pulmonary disease, were observed in both the lungs (PND 10-42) and macrophages (PND 3-42) (Figure $4 \mathrm{~b}$ ). Specifically, the positive association of DEGs in this study with human DEG disease signatures is seen at the later time points (PND 10 and PND 42). These two time points reflect the establishment and maintenance of the chronic lung disease state in this model. Thus, it is not surprising that they reflect the human tissue better than the earlier time points, since human disease signatures are derived from tissue of patients with established disease, and for the most part, except for BPD, they reflect diseases development that occurs in already mature human lungs.

\section{Evidence for time-dependent M1 and M2 polarization in Scnn 1b-Tg macrophages}

Because of our interest in the state of pulmonary macrophages in response to disease development, the expression of M1 and M2 markers (Additional file 6: Results file S4) compiled after extensive literature review [44-47] was carefully examined, and the results summarized in heatmaps (Figure 5). The heatmaps highlight the dynamic nature of the macrophage response to airway surface dehydration/defective mucus clearance. Enrichment of both M1 and M2 pathways was evident in PND 3 macrophages, but M1 signatures were particularly robust at PND 3 and M2 signatures particularly robust at PND 42. The M1 signature, while still evident, was clearly different at PND 42 compared to earlier time points, with increased expression of some genes (e.g., Cxcr1 and Cd69) and decreased expression of others genes (e.g., Nos2 and Cxcl2) compared to PND 3. Similarly, some M2 markers were exclusively high at PND 3 (e.g., Chi3l1, Illo and Mmp9), and others at PND 42 (e.g., Retnla, Chi3l4, Mrc1, Ccl17, Ccl24, 


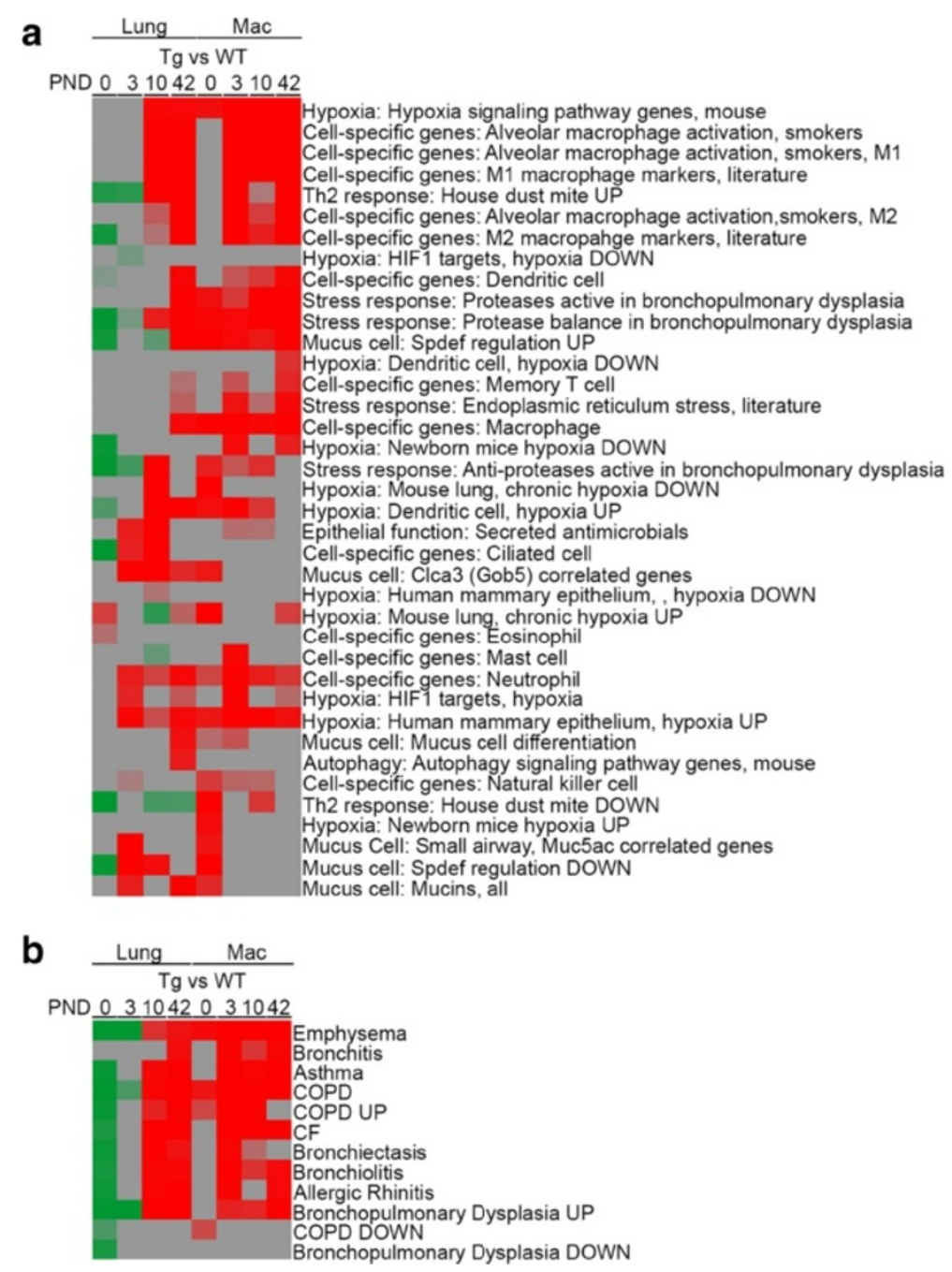

Figure 4 GSEA using custom gene sets. (a) Custom gene sets representing putatively relevant processes were used for GSEA (Additional file 4: Results file S2). The FDR values were converted into enrichment scores for clustering by the formula, score $=0.1-(0.9$ *FDR). Red and green indicated up- and down- regulation, respectively. Genes in the custom sets and their sources are described in Additional file 5: Results file S3. (b) Heat-map as described in (a) for "Respiratory Disease" pathways [41] and COPD-specific pathways [42].

Mgl2, Alox15 and Ccl22). In addition, some M1 (e.g., Cd80, Ccl3 and Socs3) and M2 (e.g., Arg1, Mmp12 and Trem2) markers were consistently up-regulated during PND 3-42 interval (Figure 5a). The M1 and M2 signatures were also identified globally in whole lung (Figure $5 \mathrm{~b}$ ). The enrichment in M2 markers at PND 42 was confirmed by evaluating protein levels of Retnla (Fizz1), Chi3l3 (YM1), and Chi3l4 (YM2) in BAL extracts (Additional file 1: Figure S5).

This activation pattern is consistent with the presence of necrotic cells and bacteria in the lungs of the Scnn1b-Tg mice at PND 3 and the requirement for macrophages to participate in their clearance via up-regulation of Th1 (M1) responses. Because Th1 responses are known to inhibit Th2 responses $[48,49]$, including mucous cell metaplastic responses, we hypothesize that the robust
Th1 (M1) responses at PND 3 and 10 dampen the Th2skewed environment normally seen in early post-natal lung development identified in this study and described elsewhere [50]. The shift to M2 polarization after PND 10 reflects the more chronic nature of lung disease, featuring mucus accumulation, but no overt bacterial colonization and normal club cell morphology and function (no necrotic cells). M2 macrophages are known to be critical for defense against atypical fungal and helminth infections [51,52], and an increase in M2-like alveolar macrophages is characteristic of many inflammatory lung diseases in both humans and mice [20], but the reason for the shift to M2 in our model is not clear. We hypothesize that this (phenomenon) is directly related to the presence of dehydrated mucus with trapped endogenous and exogenous noxious particles and the ability of the 


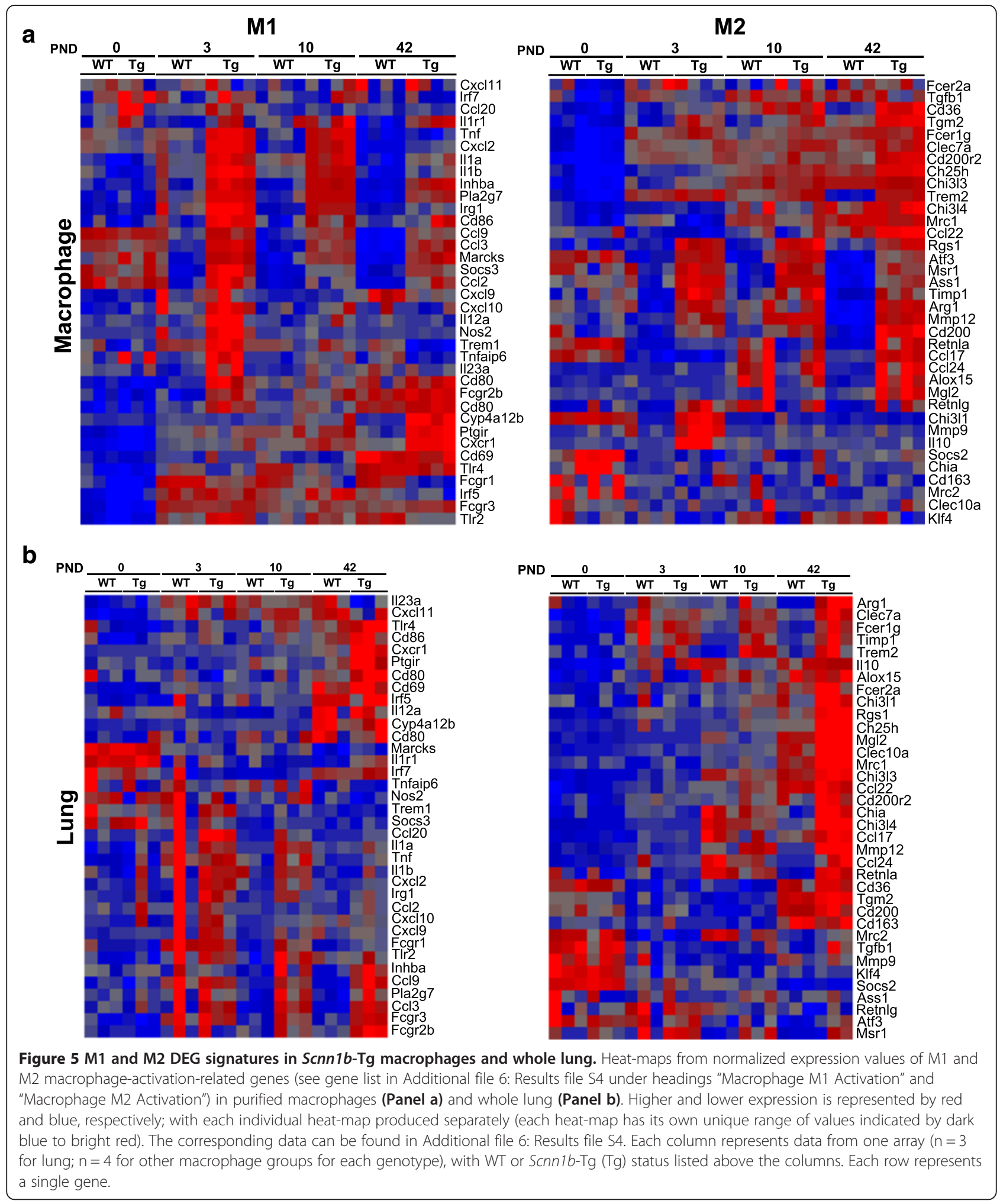

macrophages to sense the need to clear this material from the airways. This shift to M2 clearly is expected to have profound consequences, since it is not the normal state in health, and extended long-term activation of M2 macrophages is associated with the establishment of chronic lung disease [53]. Future studies should focus on defining the signals within mucus plugs that drive M2 polarization. 
The dynamic nature of both the M1 and M2 signatures, with separate groups of genes activated at different time points, also likely reflects the intrinsic variety of the pulmonary macrophage population [20]. Our sampling technique did not allow a distinction between macrophages residing in localized niches within the lung. Besides the obvious distinction between conducting airway and alveolar spaces, we postulate the existence of several sub-niches where local signals regulate local macrophage phenotypes. These would include areas of localized hypoxia, infections, necrotic/apoptotic cell death, aspiration, and mucus plugging, with the frequency and importance of each of these niches shifting across development $[54,55]$.

\section{Whole lung and macrophages produce independent inflammatory signals}

To further explore the inflammatory signals originating from, or possibly leading to, the M1 and M2 polarization patterns, the "cytokine production" node within Gene Ontology Biological Process was scrutinized (Figure 6a). At PND 0, the only signs of activation of this node were in macrophages (Figure 6b; Additional file 3: Table S3; Additional file 1: Figure S6; Additional file 7: Results file S5). Genes in this GO node were not activated in whole lung until PND 10 with signals increasing further at PND 42 (Figure 6b; Additional file 3: Table S3). While this analysis shows robust activation of the GO node related to $S c n n 1 b$-Tg expression, careful gene-level evaluation of these signatures revealed that they were primarily derived from either whole lung, e.g., Cxcl5, Chia, and $L t f$, or macrophages (many), with only a few genes producing signal from both tissues, e.g., Ccl3, Chi3l1, and Tnfrsf9 (Additional file 3: Table S3). Overall, macrophages exhibited more robust signals than whole lung, with both up-regulated and a small number of down-regulated genes identified. Because we had seen activation of a number of macrophage markers in whole lung (Additional file 3: Table S1), we hypothesized that much of the signal detected from whole lung originated from the activated macrophage population. However, it is clear from our data (Additional file 3: Table S3) that for most DEGs, the epithelial/parenchymal compartment and the macrophages uniquely contribute to the inflammatory signaling in response to airway mucus obstruction. Within each tissue, as for the M1 and M2 genes (Figure 5), DEGs tended to differ across time, e.g., genes robustly signaling in macrophages at PND 0, which were enriched for KEGG "pancreatic cancer" pathways containing Tgfb2 (not shown), were substantially different than those signaling at PND 3 (enriched for KEGG pathways containing Il6 and Tnf such as those involved in NOD-like and Toll-like receptor signaling), and those signaling at PND 42 (enriched for KEGG pathway "chemokine signaling" containing $\mathrm{Ccr}$, Ccr5, and Arrb1). While a detailed analysis of all of the

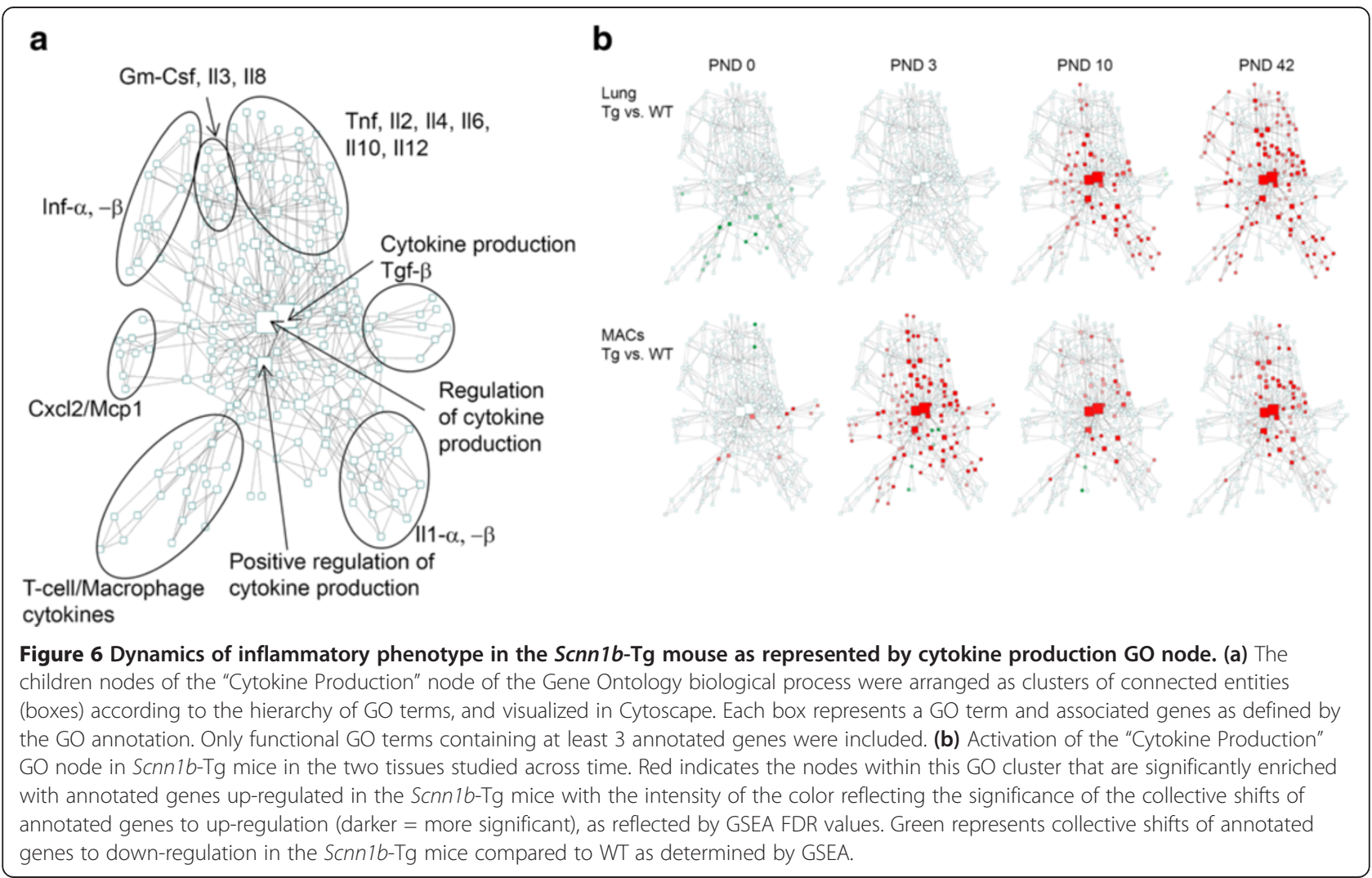


potential mechanistic insights provided by this report is beyond the scope of this publication, this study provides a framework for future efforts directed at individual signaling molecules and further highlights the usefulness of this model for a variety of pulmonary disease research questions.

\section{Scnn 1b-Tg macrophage gene signatures were comparable but more robust in GF vs. SPF environment}

GF macrophages from either WT or Scnn1b-Tg mice were very similar compared to their SPF counterparts
(Figure 3c), and only 32 genes were differentially expressed across the four groups at the selected significance threshold (Figure 7a). This result is significant because it demonstrates that macrophage activation, at least in the chronic disease state present at PND 42, is not dependent upon the presence of microbes or microbederived products, consistent with our previous discussion. By extension, macrophage activation at this stage must be in response to the consequence of epithelial transgene overexpression, namely, airway surface dehydration and the resultant mucus stasis. The gene expression findings

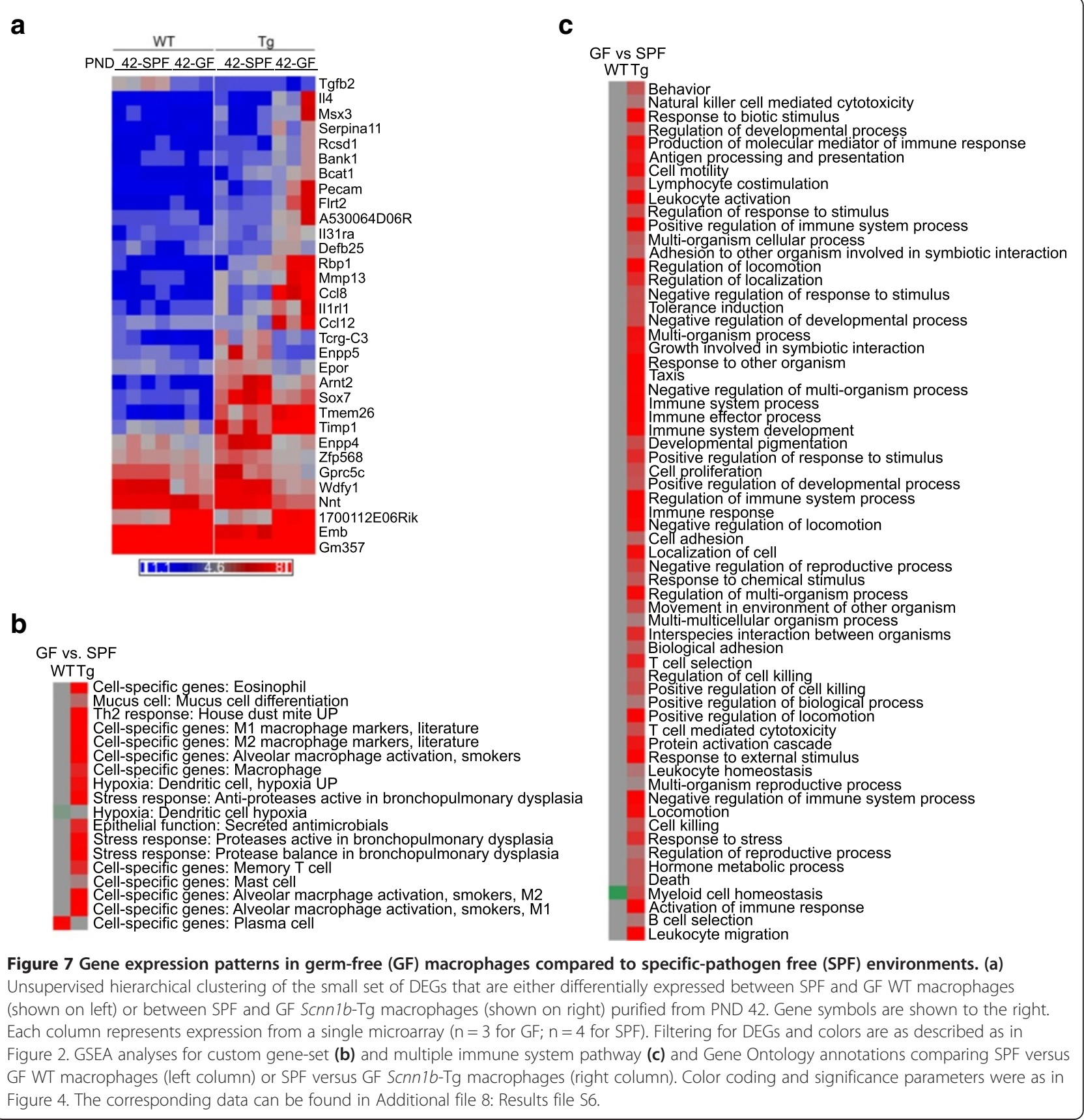


are consistent with previous histological analysis in the GF Scnn1b-Tg colony [13] and reinforce our hypothesis that, if airway surfaces are dehydrated, static mucus itself and/or abiotic materials concentrated in dehydrated mucus, trigger and maintain lung inflammation and airway remodeling.

While the differential gene expression in the GF macrophages was qualitatively similar between the GF and SPF Scnn1b-Tg macrophages (Figure 3; Additional file 1: Figure S7a), the quantitative fold-change was higher in GF compared to SPF Scnn1b-Tg mice, and GSEA analysis showed a more robust up-regulation of custom gene set (Figure 7b; Additional file 1: Figure S7a) and multiple immune system (Figure 7c) pathways in macrophages from GF compared to SPF Scnn1b-Tg mice (Additional file 8: Results file S6). We speculate that the absence of environmental bacteria and their products altered the homeostatic mechanisms that normally prevent excessive activation of resident macrophages, predisposing GF mice to exaggerated responses to external challenges, including airway surface dehydration (Additional file 1: Figure S7b). These findings are congruent with excessive activation as a key feature of gut inflammatory responses in mice raised in germ-free conditions and they highlight the role of endogenous microflora in establishment of immune homeostasis in the lung as well [56].

\section{Conclusion}

The gene expression analyses reported here provide a global appreciation for the complexity of the development of lung disease in the Scnn1b-Tg model. Importantly, the initiating stimulus in the model, i.e., mucus dehydration, is present during early postnatal life, allowing unique investigations into the relationships between a defined disease stimulus (airway surface dehydration) and postnatal lung development. This feature, which leads to emphysema, provides a setting to study the pathogenic crosstalk between mucus obstructed and inflamed airways and alveoli, processes that are likely important in children with BPD, CF, and COPD-like pediatric diseases. The Th1 airway inflammation produced as part of the "insult" transmitted from the airways to the alveolar compartments is a likely culprit in the Scnn1b-Tg mice. Our studies also reveal macrophages as early responders to airway mucus stasis and as possible communicators of inflammatory signals from the airways to the alveoli.

In contrast, the gene expression changes identified during the chronic stage of disease are more reflective of typical adult onset muco-obstructive lung diseases. Moving forward, separating the two phase of disease will be necessary to define pathogenic mechanisms. The complexity of gene signatures additionally point toward the necessity of considering cell-specific, and even site-specific, signals in future studies. Further evaluation of cell-specific lineages, including those of airway epithelial cells and macrophages purified from different lung compartments (e.g., airways vs alveolar, mucus embedded $v s$ free), will be invaluable to generate an integrated picture of the pathways leading to lung disease in this model and likely inform translational therapeutic efforts.

\section{Availability of supporting data}

Data Repository: Please use the following URL in order to access our private GEO database. "http://www.ncbi. nlm.nih.gov/geo/query/acc.cgi?acc=GSE47551".

Additional Supporting Data Files: This file summarizes the information about supplemental files associated with the manuscript titled: "Gene Expression in Whole Lung and Pulmonary Macrophages Reflects the Dynamic Pathology Associated with Airway Surface Dehydration".

\section{Additional files}

Additional file 1: Figure S1. Principal component analysis (PCA). PCA of gene expression from WT and Scnn $1 b$-Tg whole lung and purified BAL macrophages. Figure S2. Lung Gene Set Enrichment Analysis (GSEA). Heatmap representing top level GO and more stringent GSEA enrichment signals in whole lung between WT and Scnn1b-Tg mice at the four times studied. To fit the result into a legible figure, only top level ( 1 and 2 levels down from the root vocabulary term) GO biological processes and more stringent enrichment score were used as a functional annotation for this figure (Additional file 4: Results file S2). Results were considered significant when FDR $<1 \%$. The FDR values were converted into enrichment scores by the formula: score $=0.01-(0.9 *$ FDR $)$. Red and green indicate up- and down- regulation, respectively. Figure S3. Macrophage Purification. Representative images showing (a) freshly isolated, unprocessed cells from BALF, (b) purified Ly6G-negative macrophages, and (c) Ly6G positive cells after removal of the Ly6G negative cells shown in (b). Figure S4. GSEA from purified macrophages. Heatmap representing top level GO signals in macrophages between WT and Scnn 16 -Tg mice at the four times studied (Additional file 4: Results file S2). Details of the analysis are provided in legend to Additional file 5: Figure S2. Figure S5. Western blot analyses for M2 macrophage activation markers (Chi3l3, Chi3|4 and Retnla) on protein extracts from purified macrophages from PND 42 WT and Scnn 16 -Tg mice. Figure S6. Heat-map of fold changes between Scnn $1 b$-Tg and WT mice across tissues of expressed genes (Additional file 7: Results file S5) in the "Cytokine Production" GO node, whose mean log2 intensities are greater than 5 in at least one sample group in whole lung or macrophages. Figure S7. M1 and M2 macrophage-activation gene signatures in germ-free (GF) and specific pathogen free (SPF) mice.

Additional file 2: Results file S1. This excel file contains tables of log2 normalized intensity values for named genes used to generate hierarchical clustering heat-maps in figures indicated by the name of the tables. The original excel file for further analyses will be made available in the supplementary section. To generate the heat-maps, choose one of the 3 gene identifier columns, e.g. "gene symbol" and save the spreadsheet table as tab-delimited text file as input to any software tool designed to clustering microarray data. "Lung_Fig1b_time_cluster" worksheet (for Figure 1b), "Lung_Fig2_BvsWT_cluster" worksheet (for Figure 2), "MAC_Fig3b_time_cluster" worksheet (for Figure 3b), "MAC_Fig3c_BvsWT_cluster" worksheet (for Figure 3c).

Additional file 3: Table S1. Functional and Gene Ontology Terms associated with the differentially expressed genes between Scnn 1b-Tg and WT whole lung as outlined in Table 3. Functional categories are based upon author annotations from a literature review. Table S2. Percent Cell Counts (Percentage) on Purified Macrophage Fractions. Table S3. Top cytokine signaling gene level table corresponding to the "Cytokine Signaling" Gene Ontology pathway results for differential gene 
expression in whole lung and macrophages comparing Scnnlb-Tg mice to WT at the time points indicated. Genes are grouped into categories based upon the characteristics defined in the headings. Genes are only shown if the fold-change was \pm 2 -fold for any condition. Light red indicates up-regulation in Scnn $1 b$-Tg compared to WT. Green indicates down-regulation.

Additional file 4: Results file S2. This excel file contains tables of converted enrichment significance score from GSEA results for clustering analysis. The names of the individual worksheets indicate corresponding figures (Figure 4a and b; Figures S2 and S4) that show the clusters based on the specific data. For each table, GSEA results from relevant individual comparisons were extracted using a specified FDR cutoff, $T$ (e.g. 0.1 or 0.01 ) in at least one of the comparisons. The pooled FDR values $(F)$ were then converted to the enrichment score $(S)$ by the following formula: $S=T-(0.9 * F)$ contained in these tables for clustering.

Additional file 5: Results file S3. This excel file containing custom gene sets using in the GSEA analysis described in the manuscript. The supporting files containing literature reference can be found in Additional file 5: Results file S3 References. The format is in .gmt as documented by GSEA (http://www.broadinstitute.org/gsea/). To use them in GSEA analysis, export the table from Excel as tab-delimited text file, then rename the text file with .txt extension to .gmt file, and use as GSEA input according to GSEA user guide.

Additional file 6: Results file S4. This excel file containing expression values of $\mathrm{M} 1$ and $\mathrm{M} 2$ custom gene set in macrophages and whole lung that were used to generate Figure 5 and Additional file 1: Figure S7.

Additional file 7: Results file S5. This excel file contains data tables for Figure 6. For each comparison between Scnn1b-Tg vs WT, GSEA enrichment summary tables (consult http://www.broadinstitute.org/gsea/ documentation for output format) GO biological process terms branching off from "Cytokine production" were copied into each spreadsheet table as indicated in the table name. To regenerate the results, GO terms were displayed as connected networks by Cytoscape (http://www.cytoscape. org/) and the FDR values were used to convert to enrichment scores described above, from each GSEA summary table saved as tab-delimited text files were used to decorate the GO term nodes as color intensities. The fold change values for "Cytokine production" genes were filtered at minimal of 1.5 fold change between Scnn1b-Tg and WT mice for at least 1 time point, then used for clustering in Additional file 1: Figure $\mathbf{S 6}$ are in "CytoGene_fold_change_1.5" worksheet.

Additional file 8: Results file S6. This excel file contains log2 normalized intensity values of genes in macrophages from GF and SPF conditions. This data was used to generate Figure 7.

\section{Competing interests}

The authors declare that they have no competing interest.

\section{Authors' contributions}

ALB, YS, EJK, LCJ performed animal necropsies and collected various tissues analyzed in this study. YS carried out the macrophage isolation, RNA isolation and western blot studies. HD performed bioinformatics and statistical analyses. YS, ALB, HD and WKO prepared custom gene lists. RCB, WKO, YS, ALB conceived and designed the study. YS, ALB, WKO and RCB drafted and finalized the manuscript. All authors read and approved the final manuscript.

\section{Authors' information}

Co-senior authors: Wanda K O'Neal and Richard C Boucher.

\section{Acknowledgements}

We thank Michael J. Vernon, UNC Functional Genomic Core, for help with cDNA generation and array hybridization. We thank Drs. Gang Chen and Jeffrey A. Whitsett for providing permission to publish the Spdef regulated custom gene list used for Figure 4 (Additional file 5: Results file S3). We thank Maureen A. Bower and Dr. Balfour Sartor in the UNC Center for Gastrointestinal Biology and Disease Gnotobiotic Core (supported by $\mathrm{NIH}$ grant P30 DK34987) for generating and maintaining the germ-free Scnn $1 b$-Tg mouse colony, and Syanne Olson and Emily M. Curley for editorial assistance.

\section{Grant Support}

The studies were supported by the Flight Attendant Medical Research Institute (FAMRI) grant to Y.S.; the Cystic Fibrosis Research Development Program grant RDP R026 to W.K.O., and National Institute of Health P30 DK065988, P50 HL060280, 5-P50HL-107168, and 1-P01-HL0880801A1 to R.C.B.

Received: 15 March 2014 Accepted: 15 August 2014

Published: 10 September 2014

\section{References}

1. Fahy JV, Dickey BF: Airway mucus function and dysfunction. N Engl I Med 2010, 363(23):2233-2247.

2. Boucher RC: Cystic fibrosis: a disease of vulnerability to airway surface dehydration. Trends Mol Med 2007, 13(6):231-240.

3. Smith DJ, Gaffney EA, Blake JR: Modelling mucociliary clearance. Respir Physiol Neurobiol 2008, 163(1-3):178-188.

4. James AL, Wenzel S: Clinical relevance of airway remodelling in airway diseases. Eur Respir J 2007, 30(1):134-155.

5. Randell SH, Boucher RC: Effective mucus clearance is essential for respiratory health. Am J Respir Cell Mol Biol 2006, 35(1):20-28.

6. Rogers GB, Carroll MP, Serisier DJ, Hockey PM, Jones G, Bruce KD: Characterization of bacterial community diversity in cystic fibrosis lung infections by use of $16 \mathrm{~s}$ ribosomal DNA terminal restriction fragment length polymorphism profiling. J Clin Microbiol 2004, 42(11):5176-5183.

7. Ellerman A, Bisgaard $\mathrm{H}$ : Longitudinal study of lung function in a cohort of primary ciliary dyskinesia. Eur Respir J 1997, 10(10):2376-2379.

8. Sze MA, Dimitriu PA, Hayashi S, Elliott WM, McDonough JE, Gosselink JV, Cooper J, Sin DD, Mohn WW, Hogg JC: The lung tissue microbiome in chronic obstructive pulmonary disease. Am J Respir Crit Care Med 2012, 185(10):1073-1080.

9. Mall M, Grubb BR, Harkema JR, O'Neal WK, Boucher RC: Increased airway epithelial $\mathrm{Na}+$ absorption produces cystic fibrosis-like lung disease in mice. Nat Med 2004, 10(5):487-493.

10. Livraghi-Butrico A, Grubb BR, Kelly EJ, Wilkinson KJ, Yang H, Geiser M, Randell SH, Boucher RC, O'Neal WK: Genetically determined heterogeneity of lung disease in a mouse model of airway mucus obstruction. Physiol Genomics 2012, 44(8):470-484.

11. Wielputz MO, Eichinger M, Zhou Z, Leotta K, Hirtz S, Bartling SH, Semmler W, Kauczor HU, Puderbach M, Mall MA: In vivo monitoring of cystic fibrosis-like lung disease in mice by volumetric computed tomography. Eur Respir J 2011, 38(5):1060-1070

12. Mall MA, Harkema JR, Trojanek JB, Treis D, Livraghi A, Schubert S, Zhou Z, Kreda SM, Tilley SL, Hudson EJ, O'Neal WK, Boucher RC: Development of chronic bronchitis and emphysema in beta-epithelial $\mathrm{Na}+$ channel-overexpressing mice. Am J Respir Crit Care Med 2008, 177(7):730-742.

13. Livraghi-Butrico A, Kelly EJ, Klem ER, Dang H, Wolfgang MC, Boucher RC, Randell SH, O'Neal WK: Mucus clearance, MyD88-dependent and MyD88independent immunity modulate lung susceptibility to spontaneous bacterial infection and inflammation. Mucosal Immunol 2012, 5(4):397-408.

14. Amy RW, Bowes D, Burri PH, Haines J, Thurlbeck WM: Postnatal growth of the mouse lung. J Anat 1977, 124(Pt 1):131-151.

15. Speer CP: Chorioamnionitis, postnatal factors and proinflammatory response in the pathogenetic sequence of bronchopulmonary dysplasia. Neonatology 2009, 95(4):353-361.

16. Velten M, Heyob KM, Rogers LK, Welty SE: Deficits in lung alveolarization and function after systemic maternal inflammation and neonatal hyperoxia exposure. J Appl Physiol (1985) 2010 108(5):1347-1356.

17. Svanes C, Sunyer J, Plana E, Dharmage S, Heinrich J, Jarvis D, de Marco R, Norback D, Raherison C, Villani S, Wjst M, Svanes K, Antó JM: Early life origins of chronic obstructive pulmonary disease. Thorax 2010, 65(1):14-20.

18. Stocks J, Sonnappa S: Early life influences on the development of chronic obstructive pulmonary disease. Ther Adv Respir Dis 2013, 7(3):161-173.

19. Livraghi A, Grubb BR, Hudson EJ, Wilkinson KJ, Sheehan JK, Mall MA, O'Nea WK, Boucher RC, Randell SH: Airway and lung pathology due to mucosal surface dehydration in \{beta\}-epithelial $\mathrm{Na}+$ channel-overexpressing mice: role of TNF-\{alpha\} and IL-4R\{alpha\} signaling, influence of neonatal development, and limited efficacy of glucocorticoid treatment. J Immunol 2009, 182(7):4357-4367. 
20. Hussell T, Bell TJ: Alveolar macrophages: plasticity in a tissue-specific context. Nat Rev Immunol 2014, 14(2):81-93.

21. Snelgrove RJ, Goulding J, Didierlaurent AM, Lyonga D, Vekaria S, Edwards L, Gwyer E, Sedgwick JD, Barclay AN, Hussell T: A critical function for CD200 in lung immune homeostasis and the severity of influenza infection. Nat Immunol 2008, 9(9):1074-1083.

22. Bonfield TL, Konstan MW, Burfeind P, Panuska JR, Hilliard JB, Berger M: Normal bronchial epithelial cells constitutively produce the anti-inflammatory cytokine interleukin-10, which is downregulated in cystic fibrosis. Am J Respir Cell Mol Biol 1995, 13(3):257-261.

23. Trojanek JB, Cobos-Correa A, Diemer S, Kormann M, Schubert SC, Zhou-Suckow Z, Agrawal R, Duerr J, Wagner CJ, Schatterny J, Hirtz S, Sommerburg O, Hartl D, Schultz C, Mall MA: Airway mucus obstruction triggers macrophage activation and MMP12-dependent emphysema. Am J Respir Cell Mol Biol 2014, [Epub ahead of print]

24. Rowe SM, Jackson PL, Liu G, Hardison M, Livraghi A, Solomon GM, McQuaid DB, Noerager BD, Gaggar A, Clancy JP, O'Neal W, Sorscher EJ, Abraham E, Blalock JE: Potential role of high-mobility group box 1 in cystic fibrosis airway disease. Am J Respir Crit Care Med 2008, 178(8):822-831.

25. Fleming TJ, Fleming ML, Malek TR: Selective expression of Ly-6G on myeloid lineage cells in mouse bone marrow. RB6-8C5 mAb to granulocyte-differentiation antigen $(\mathrm{Gr}-1)$ detects members of the Ly- 6 family. J Immunol 1993, 151(5):2399-2408.

26. Benjamini $Y$, Hochberg $Y$ : Controlling the false discovery rate: a practical and powerful approach to multiple testing. J Royal Stati Soc Series B 1995, 57(1):289-300. 57 (1): 289-300.

27. de Hoon MJ, Imoto S, Nolan J, Miyano S: Open source clustering software. Bioinformatics 2004, 20(9):1453-1454.

28. Saldanha AJ: Java treeview-extensible visualization of microarray data. Bioinformatics 2004, 20(17):3246-3248

29. Smoot ME, Ono K, Ruscheinski J, Wang PL, Ideker T: Cytoscape 2.8: new features for data integration and network visualization. Bioinformatics 2011, 27(3):431-432.

30. Mariani TJ, Reed JJ, Shapiro SD: Expression profiling of the developing mouse lung: insights into the establishment of the extracellular matrix. Am J Respir Cell Mol Biol 2002, 26(5):541-548.

31. Zhang K, Shi ZM, Chang YN, Hu ZM, Qi HX, Hong W: The ways of action of long non-coding RNAs in cytoplasm and nucleus. Gene 2014, 547(1):1-9.

32. Krishnan J, Mishra RK: Emerging trends of long non-coding RNAs in gene activation. FEBS J 2014, 281(1):34-45

33. Follettie MT, Ellis DK, Donaldson DD, Hill AA, DiesI V, DeClercq C, Sypek JP, Dorner AJ, Wills-Karp M: Gene expression analysis in a murine model of allergic asthma reveals overlapping disease and therapy dependent pathways in the lung. Pharmacogenomics J 2006, 6(2):141-152.

34. Munitz A, Brandt EB, Mingler M, Finkelman FD, Rothenberg ME: Distinct roles for IL-13 and IL-4 via IL-13 receptor alpha1 and the type II IL-4 receptor in asthma pathogenesis. Proc Natl Acad Sci U S A 2008, 105(20):7240-7245.

35. Adkins $B, B u Y$, Vincek $V$, Guevara $P$ : The primary responses of murine neonatal lymph node CD4+ cells are Th2-skewed and are sufficient for the development of Th2-biased memory. Clin Dev Immunol 2003, 10(1):43-51.

36. Adkins B: Development of neonatal Th1/Th2 function. Int Rev Immunol 2000, 19(2-3):157-171.

37. Groneck P, Gotze-Speer B, Oppermann M, Eiffert H, Speer CP: Association of pulmonary inflammation and increased microvascular permeability during the development of bronchopulmonary dysplasia: a sequential analysis of inflammatory mediators in respiratory fluids of high-risk preterm neonates. Pediatrics 1994, 93(5):712-718.

38. Snyder JC, Reynolds SD, Hollingsworth JW, Li Z, Kaminski N, Stripp BR: Clara cells attenuate the inflammatory response through regulation of macrophage behavior. Am J Respir Cell Mol Biol 2010, 42(2):161-171.

39. Guilliams M, De Kleer I, Henri S, Post S, Vanhoutte L, De Prijck S, Deswarte K, Malissen B, Hammad H, Lambrecht BN: Alveolar macrophages develop from fetal monocytes that differentiate into long-lived cells in the first week of life via GM-CSF. J Exp Med 2013, 210(10):1977-1992.

40. Hashimoto D, Chow A, Noizat C, Teo P, Beasley MB, Leboeuf M, Becker CD, See P, Price J, Lucas D, Greter M, Mortha A, Boyer SW, Forsberg EC, Tanaka M, van Rooijen N, García-Sastre A, Stanley ER, Ginhoux F, Frenette PS, Merad M: Tissue-resident macrophages self-maintain locally throughout adult life with minimal contribution from circulating monocytes. Immunity 2013, 38(4):792-804.
41. Chowdhary R, Tan SL, Pavesi G, Jin J, Dong D, Mathur SK, Burkart A, Narang V, Glurich I, Raby BA, Weiss ST, Wong L, Liu JS, Bajic VB: A database of annotated promoters of genes associated with common respiratory and related diseases. Am J Respir Cell Mol Biol 2012, 47(1):112-119.

42. Steiling K, van den Berge M, Hijazi K, Florido R, Campbell J, Liu G, Xiao J, Zhang X, Duclos G, Drizik E, Si H, Perdomo C, Dumont C, Coxson HO, Alekseyev YO, Sin D, Pare P, Hogg JC, McWilliams A, Hiemstra PS, Sterk PJ, Timens W, Chang JT, Sebastiani P, O'Connor GT, Bild AH, Postma DS, Lam S, Spira A, Lenburg ME: A dynamic bronchial airway gene expression signature of chronic obstructive pulmonary disease and lung function impairment. Am J Respir Crit Care Med 2013, 187(9):933-942.

43. Chen G, Korfhagen TR, XU Y, Kitzmiller J, Wert SE, Maeda Y, Gregorieff A, Clevers $H$, Whitsett JA: SPDEF is required for mouse pulmonary goblet cell differentiation and regulates a network of genes associated with mucus production. J Clin Invest 2009, 119(10):2914-2924.

44. Shaykhiev R, Krause A, Salit J, Strulovici-Barel Y, Harvey BG, O'Connor TP, Crystal RG: Smoking-dependent reprogramming of alveolar macrophage polarization: implication for pathogenesis of chronic obstructive pulmonary disease. J Immunol 2009, 183(4):2867-2883.

45. Mosser DM, Edwards JP: Exploring the full spectrum of macrophage activation. Nat Rev Immunol 2008, 8(12):958-969.

46. Gordon S, Martinez FO: Alternative activation of macrophages: mechanism and functions. Immunity 2010, 32(5):593-604.

47. Murray PJ, Wynn TA: Protective and pathogenic functions of macrophage subsets. Nat Rev Immunol 2011, 11(11):723-737.

48. Mitchell C, Provost K, Niu N, Homer R, Cohn L: IFN-gamma acts on the airway epithelium to inhibit local and systemic pathology in allergic airway disease. J Immunol 2011, 187(7):3815-3820.

49. Daan De Boer J, Roelofs JJ, De Vos AF, De Beer R, Schouten M, Hommes TJ, Hoogendijk AJ, De Boer OJ, Stroo I, van der Zee JS, Veer CV, van der Poll T: Lipopolysaccharide inhibits Th2 lung inflammation induced by house dust mite allergens in mice. Am J Respir Cell Mol Biol 2013, 48(3):382-389.

50. Adkins B, Leclerc C, Marshall-Clarke S: Neonatal adaptive immunity comes of age. Nat Rev Immunol 2004, 4(7):553-564

51. Nelson MP, Christmann BS, Werner JL, Metz AE, Trevor JL, Lowell CA, Steele C: IL-33 and M2a alveolar macrophages promote lung defense against the atypical fungal pathogen Pneumocystis murina. J Immunol 2011 186(4):2372-2381.

52. Reece JJ, Siracusa MC, Scott AL: Innate immune responses to lung-stage helminth infection induce alternatively activated alveolar macrophages. Infect Immun 2006, 74(9):4970-4981.

53. Kim EY, Battaile JT, Patel AC, You Y, Agapov E, Grayson MH, Benoit LA, Byers DE, Alevy Y, Tucker J, Swanson S, Tidwell R, Tyner JW, Morton JD, Castro M, Polineni D, Patterson GA, Schwendener RA, Allard JD, Peltz G, Holtzman MJ: Persistent activation of an innate immune response translates respiratory viral infection into chronic lung disease. Nat Med 2008, 14(6):633-640.

54. Cocco RE, Ucker DS: Distinct modes of macrophage recognition for apoptotic and necrotic cells are not specified exclusively by phosphatidylserine exposure. Mol Biol Cell 2001, 12(4):919-930.

55. Murdoch C, Muthana M, Lewis CE: Hypoxia regulates macrophage functions in inflammation. J Immunol 2005, 175(10):6257-6263.

56. Souza DG, Vieira AT, Soares AC, Pinho V, Nicoli JR, Vieira LQ, Teixeira MM: The essential role of the intestinal microbiota in facilitating acute inflammatory responses. J Immunol 2004, 173(6):4137-4146.

doi:10.1186/1471-2164-15-726

Cite this article as: Saini et al:: Gene expression in whole lung and pulmonary macrophages reflects the dynamic pathology associated with airway surface dehydration. BMC Genomics 2014 15:726. 